\title{
Corals on the slope (Aptian, Maestrat Basin, Spain)
}

\author{
Telm Bover-Arnal ${ }^{\mathrm{a}, *}$, Hannes Löser ${ }^{\mathrm{b}}$, Josep Anton Moreno-Bedmar ${ }^{\mathrm{c}}$, Ramon Salas ${ }^{\mathrm{d}}$, André Strasser ${ }^{\mathrm{a}}$ \\ a Département de Géosciences, Université de Fribourg, Chemin du Musée 6, 1700 Fribourg, Switzerland \\ ${ }^{\mathrm{b}}$ Estación Regional del Noroeste, Instituto de Geología, Universidad Nacional Autónoma de México, Blvd. Luis Donaldo Colosio y Madrid s/n, 83250 Hermosillo, Sonora, Mexico \\ ${ }^{\mathrm{c}}$ Instituto de Geología, Universidad Nacional Autónoma de México, Ciudad Universitaria, Coyoacán, 04510 México DF, Mexico \\ ${ }^{\mathrm{d}}$ Departament de Geoquímica, Petrologia i Prospecció Geològica, Facultat de Geologia, Universitat de Barcelona, Martí i Franqués s/n, 08028 Barcelona, Spain
}

\begin{abstract}
The term "reef" has been frequently misused when applied to fossil coral communities. Our popular but biased view of coral community structure based on the idyllic picture of recent tropical reefs has failed to recognize that, in many fossil examples, alternative states of community structure with no or limited framework may occur. The Aptian colonial scleractinians analysed in the western Maestrat Basin (eastern Spain) constitute an example of non-reef-building coral populations, which thrived in marly slope settings. These corals developed within the photic zone but below the storm wave-base. All colonies are found well-preserved in life position. They are mostly decimetres in size and mainly occur isolated giving rise to a continuous and uniform (dominated by domal and massive forms) unbound growth fabric with a low to medium degree of development (coral skeletal volume $=5-20 \%$ ). Occasionally, however, colonies growing on top of each other forming small metre-sized bioherms are also present. A total of 21 species were identified. Coral diversity in each sample location varies between three and nine species. These numbers of species are comparable with those exhibited by coeval coral assemblages from other basins of the Tethys, but are comparatively low when compared with diversities exhibited by many Recent and fossil coral communities. The corals studied apparently found optimal ecological conditions for their development on the marly slopes of the western Maestrat Basin. This is primarily expressed in the unusually large dimensions (up to $2.3 \mathrm{~m}$ in width) of some of the coral colonies when compared to other Cretaceous occurrences, and in the persistence and resilience of the coral populations. The observed coral genera and species (suborders Archeocaeniina, Faviina, Fungiina and Microsolenina) are very common in the time interval between the Barremian and the Early Albian and most of them have been reported from several other localities in the western and central Tethyan realm. In addition, the coral-bearing levels also contain the poorly known and exotic genera Agrostyliastraea and Procladocora. There are no significant differences at species level or in community structure between the Early and Late Aptian faunas investigated. Therefore, the coral communities as well as the environmental conditions controlling them would have been relatively stable during the time intervals when these corals flourished. An important palaeoecological implication is that comparatively low species diversities and the absence of reef frameworks do not necessarily imply unfavourable environmental conditions for coral growth. Furthermore, this study may serve as an example for the analysis of other level-bottom coral communities displaying a loose growth fabric.
\end{abstract}

\section{Introduction}

Early Cretaceous scleractinian corals reached their maximum radiation and species diversity during the Barremian-Aptian time interval (Löser, 1998, 2005). Throughout this time, coral faunas together with rudist bivalves and orbitolinid foraminifera were

\footnotetext{
* Corresponding author.

E-mail address: telm.boverarnal@unifr.ch (T. Bover-Arnal).
}

common organisms of the tropical and subtropical carbonate systems flourishing along the margins of the Tethys Ocean (e.g., Castro et al., 2008; Schroeder et al., 2010; Skelton and Gili, 2012).

The study of Early Cretaceous scleractinian assemblages, and of other Mesozoic coral communities, is of importance given that their community structure is often not comparable to the one of their modern counterparts, which can become primary framework builders and generate large and extensive, wave-resistant constructions in relatively shallow, low-latitude marine settings (Kennedy and Woodroffe, 2002; Montaggioni, 2005). In contrast, 
Cretaceous coral associations mainly corresponded to level-bottom communities (sensu Riding, 2002), occurring as isolated colonies of small size (less than $50 \mathrm{~cm}$ in diameter) or building small bioherms in low-energy platform and slope environments (e.g., Scholz, 1984; Sanders and Baron-Szabo, 2005; Tomás et al., 2008).

Taxonomic studies of Early Cretaceous coral faunas are numerous (e.g., Löser, 1994). Accordingly, during the last few decades, knowledge of the stratigraphic ranges and palaeobiogeographic distribution of the different species has improved significantly. However, their palaeoecology has received little attention (Aillud, 2001; Clack, 2001; Götz et al., 2005; Tomás et al., 2008). This may be owing to the rarity of reef frameworks found in the Early Cretaceous, making palaeoecological studies less attractive. On the other hand, Jurassic coral populations, commonly associated with stromatoporoids, chaetetids, microbialites and sponges giving rise to metre-sized bioherms and biostromes, have been widely studied by integrating taxonomy and palaeoecology (e.g., Turnšek et al., 1981; Leinfelder, 1993; Insalaco, 1996; Insalaco et al., 1997;
Helm and Schülke, 1998, 2006; Dupraz and Strasser, 1999, 2002; Lathuilière, 2000a, b; Lathuilière et al., 2005; Olivier et al., 2004, 2006, 2007; Reolid et al., 2009; Rusciadelli et al., 2011).

The interpretation of the palaeoecology of Mesozoic scleractinian assemblages is always a challenge. First, the large Pleistocene, Holocene and recent reef frameworks cannot be used as reliable analogues given that these constructions, which are mainly associated with warm, clear waters, do not fit with the community structure exhibited by many Mesozoic coral populations. Second, the effects of the physico-chemical factors controlling coral faunas such as salinity, temperature, light penetration, trophic level, sediment supply, hydrodynamic energy, and aragonite saturation are difficult, if not impossible, to constrain in the geological record. The same is true for the effects of biotic competition and interaction. And lastly, poor exposure conditions, tectonic deformations, and the fact that outcrops are often small and limited to two dimensions, frequently make it impossible to recognize the exact position of the coral colonies along a platform-to-basin profile.
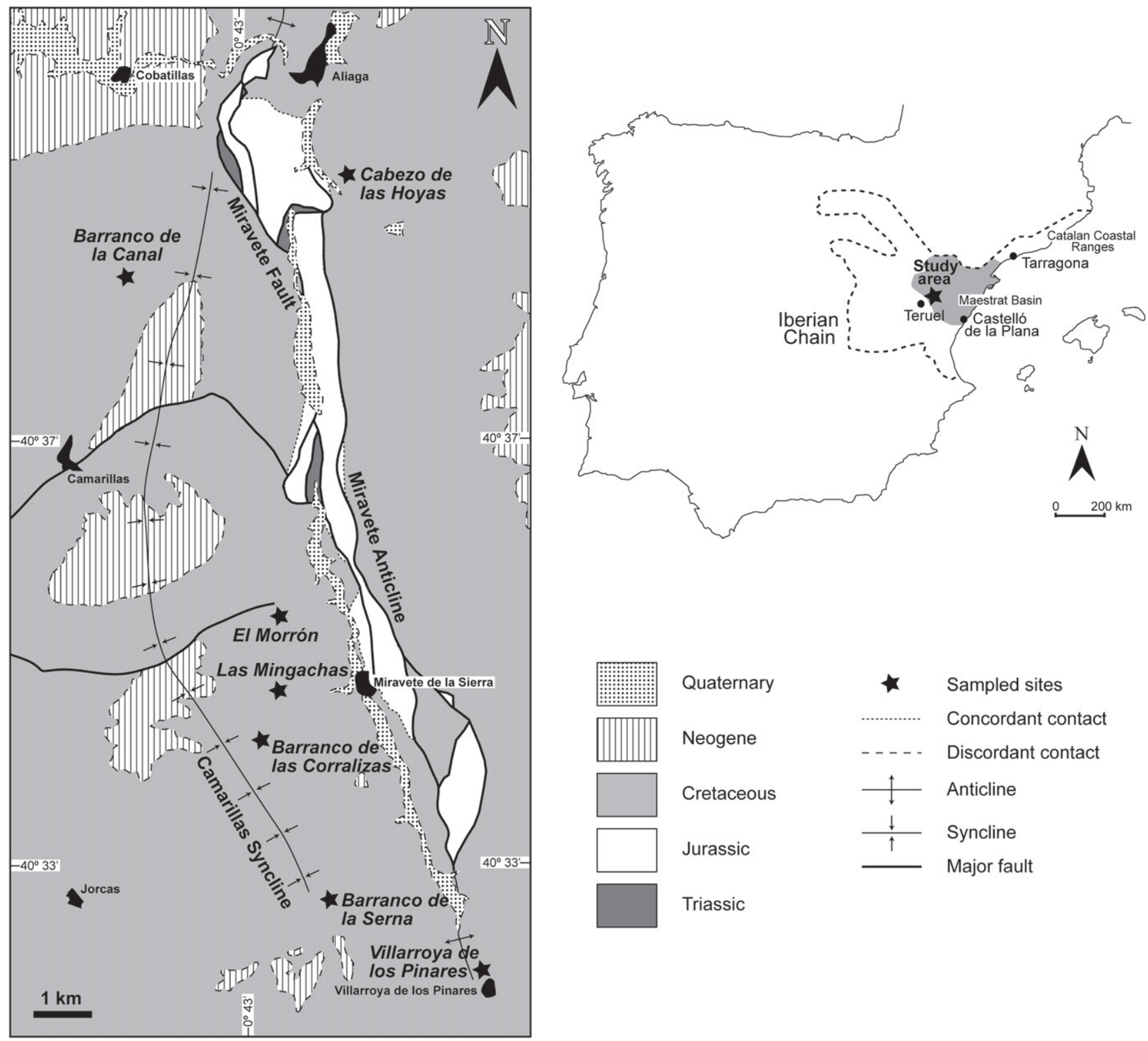

Quaternary

Neogene

Cretaceous

Jurassic

Triassic

Fig. 1. Location of the study area in the western Maestrat Basin (eastern Iberian Chain; eastern Spain) and geological map of the central part of the Galve Sub-basin. Modified after Canérot et al. (1979) and Gautier (1980). The positions of the outcrops sampled for the present study are marked with a black star. 
The western Maestrat Basin (eastern Iberian Chain, Spain) exhibits superbly exposed and continuous three-dimensional platform-to-basin transects rich in autochthonous coral communities of Aptian age (Bover-Arnal et al., 2009, 2010). Therefore, all coral specimens can be ascribed to a specific depositional setting. So far, the taxonomy and palaeoecology of Early Cretaceous scleractinian assemblages from the Maestrat Basin have been investigated by Götz et al. (2005) in Hauterivan deposits of the central part of the basin, and by Tomás et al. (2008) in Late Aptian strata of the southern part. The Aptian coral communities from the western Maestrat Basin are here described for the first time, involving systematic palaeontology and palaeocology. In this area, colonial corals are found in limestones, marly limestones or marls, in platform and slope settings (Vennin and Aurell, 2001; Bover-Arnal et al., 2009, 2010, 2011a; Embry et al., 2010). The present study is focused exclusively on well-preserved colonies found in marls and marly limestones in slope environments. The corals found in pure limestone in platform and slope settings commonly are strongly recrystallized and do not permit taxonomic determination at species level. Furthermore, obtaining samples large enough for producing thin sections for taxonomic determinations from uniformly weathered massive limestone rocks is hardly possible with conventional field equipment.

The objectives of the present paper are to (1) report the community structure of Aptian coral assemblages, which unquestionably thrived on marly slopes; (2) taxonomically characterize the coral assemblages; (3) compare them with coeval Tethyan communities to define compositional differences and similarities as well as the palaeobiogeographic distribution of each species; and (4) discuss the palaeoenvironmental controls. The study is of significance in that it provides a reliable palaeoecological analogue of other Cretaceous coral populations.

\section{Geological setting}

The Aptian sedimentary succession containing the coral faunas analysed is found in the eastern part of the Iberian Chain, in the surroundings of the Aliaga Geological Park and the villages of Aliaga, Miravete de la Sierra, Camarillas, Jorcas and Villarroya de los Pinares (Teruel Province, eastern Spain; Fig. 1). The Iberian Chain was formed by the inversion of Mesozoic rift basins during the Paleogene-Early Miocene time interval (Salas and Casas, 1993; Salas et al., 2001). The material studied belongs to the Galve Sub-basin, which corresponds to the western marginal part of the Maestrat Basin (Salas and Guimerà, 1996).

The Aptian strata of the Maestrat Basin can be divided into six formations: Morella, Cervera del Maestre, Xert, Forcall, Villarroya de los Pinares and Benassal (Canérot et al., 1982; Salas et al., 2001, Fig. 2). The Morella Formation is constituted by fluvial deposits with tidal influence characterized by the presence of dinosaur remains. The Cervera del Maestre Formation is composed of sandy marls, sandy limestones and sandstones formed in shallow-marine and peritidal settings. This formation contains an interval of reversed magnetic polarity interpreted as the M0r by Salas et al. (2005) and thus would be earliest Aptian in age. However, López Llorens (2007) found an ammonite belonging to the Imerites giraudi Biozone within the Morella Formation in the close-by subbasin of Morella in the northern part of the Maestrat Basin. Therefore, a Late Barremian age for these two latter formations, or at least for the Morella Formation, should not be ruled out. The rocks of the Xert, Forcall, Villarroya de los Pinares and Benassal formations were generated in subtropical to tropical carbonate neritic settings, which were occasionally influenced by significant siliciclastic input. The Xert Formation lacks age-diagnostic fauna. According to Canérot (1974) and Salas et al. (2001, 2005), it is

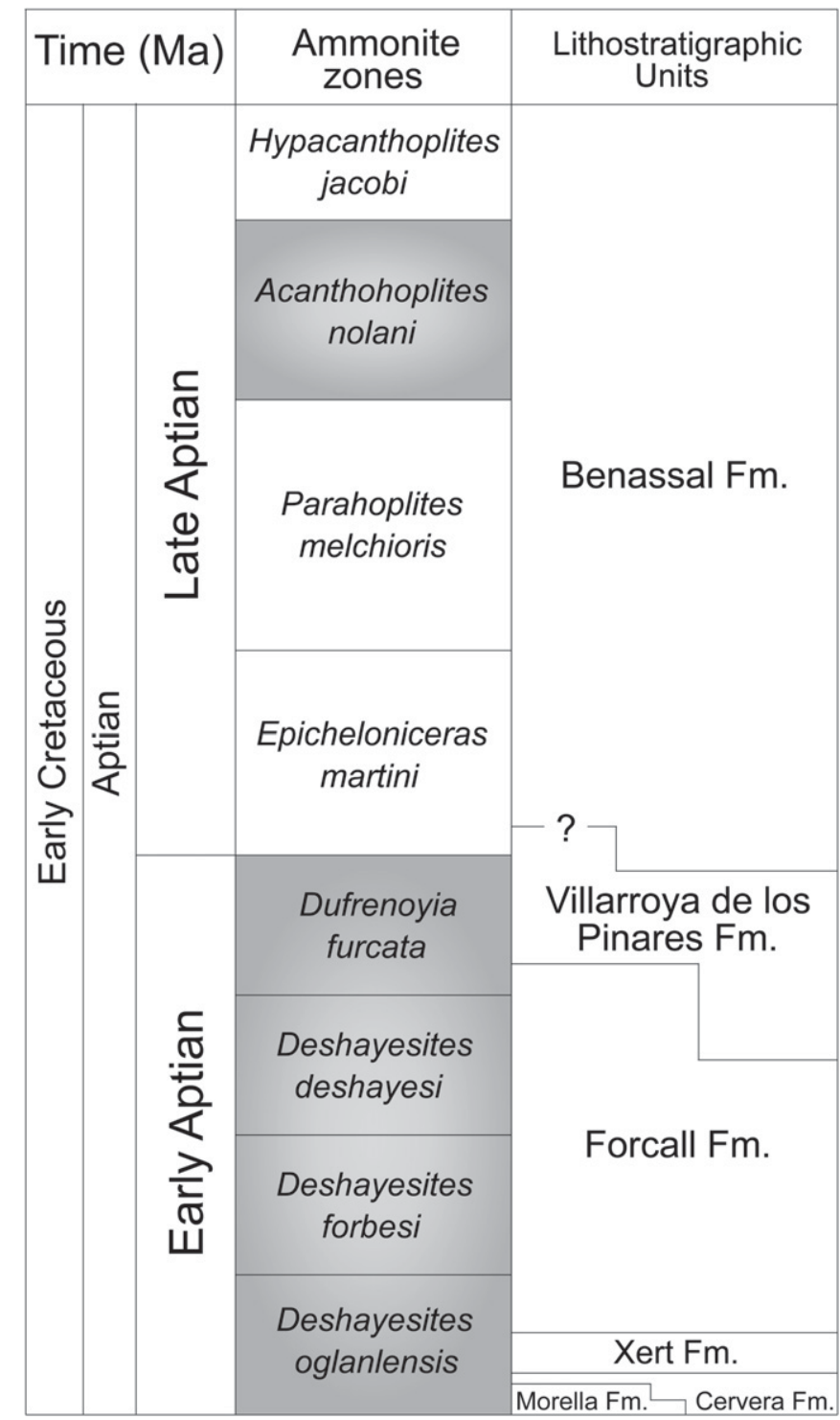

Fig. 2. Chrono-, bio- and lithostratigraphic framework for the Aptian in the Maestrat Basin. Identified ammonite zones are indicated in grey (Weisser, 1959; MorenoBedmar et al., 2009, 2010).

interpreted to be Early Aptian in age; however, a latest Barremian age cannot be discarded. Based on ammonite, rudist and orbitolinid biostratigraphy, the Forcall Formation is of Early Aptian age, whereas the boundaries of the Villarroya de los Pinares and Benassal formations can be strongly diachronous across the basin (Fig. 2; Weisser, 1959; Cánerot et al., 1982; Moreno-Bedmar et al., 2009, 2010; Bover-Arnal et al., 2010, 2011a). The age of the base of the Villarroya de los Pinares Formation varies within the time period encompassed by the Deshayesites deshayesi and Dufrenoyia furcata ammonite biozones (Early Aptian). The limit between the Villarroya de los Pinares and Benassal formations in most parts of the Maestrat Basin is latest Early Aptian, but in proximal areas of the Galve Sub-basin this boundary could be earliest Late Aptian. The corals collected for the present study belong to the Dufrenoyia furcata (Villarroya de los Pinares Formation) and the Epicheloniceras martini (Benassal Formation) biozones (Fig. 2; Bover-Arnal et al., 2009, 2010).

In the Galve Sub-basin, the Villarroya de los Pinares and Benassal formations crop out along the limbs of two major Tertiary 
folds: the Miravete anticline and the Camarillas syncline (Fig. 1). The stratigraphic intervals studied range between 2 and $50 \mathrm{~m}$ thick and are characterized mainly by an alternation of deposits shed from the platform top and coral-dominated marls, which formed at the platform-to-basin transition (Bover-Arnal et al., 2009, 2010).

\section{Sample location and methods}

A total of 138 coral samples, including fragments as well as entire colonies, were collected from seven different localities throughout the Galve Sub-basin to obtain a sub-basin-wide representation of the coral populations (Fig. 1). Corals were collected in marls and marly limestones in slope settings. In order not to destroy the fossil heritage of the Galve Sub-basin, fewer than $10 \%$ of the colonies observed were sampled. The sampling criterion in each location was to select coral colonies exhibiting distinct growth forms and arrangement of corallites in order to sample as many different species as possible. The geographical distribution and age of the coral faunas collected is as follows: Barranco de la Canal, 21 samples of early Late Aptian age; Barranco de la Serna, 16 samples of late Early Aptian age; Cabezo de las Hoyas, 17 samples of early Late Aptian age; Barranco de las Corralizas, 50 samples of early Late Aptian age; El Morrón, 17 samples of late Early Aptian age; Las Mingachas, 14 samples of late Early Aptian age; Villarroya de los Pinares, 3 samples of early Late Aptian age. From this material, 180 longitudinally and transversely orientated thinsections were produced to identify the corals. Although strongly recrystallized specimens do occur, most of the material exhibits a good state of preservation and only shows minor recrystallization. However, skeletal microstructures are almost unrecognizable. The thin sections are stored under the numbers 78434-78491 in the collection of the Museu Geològic del Seminari de Barcelona (MSGB), Spain. Panoramic photomosaics of the platform-to-basin depositional profiles were used to map the palaeotopographical distribution of the sampled colonial corals.

\section{Coral facies and habitat}

The scleractinian colonies studied occur in growth position, in marls and marly limestone deposits corresponding to ancient slope environments (Figs. 3-5). The levels rich in autochthonous coral faunas are between $40 \mathrm{~cm}$ and $10 \mathrm{~m}$ thick and alternate with
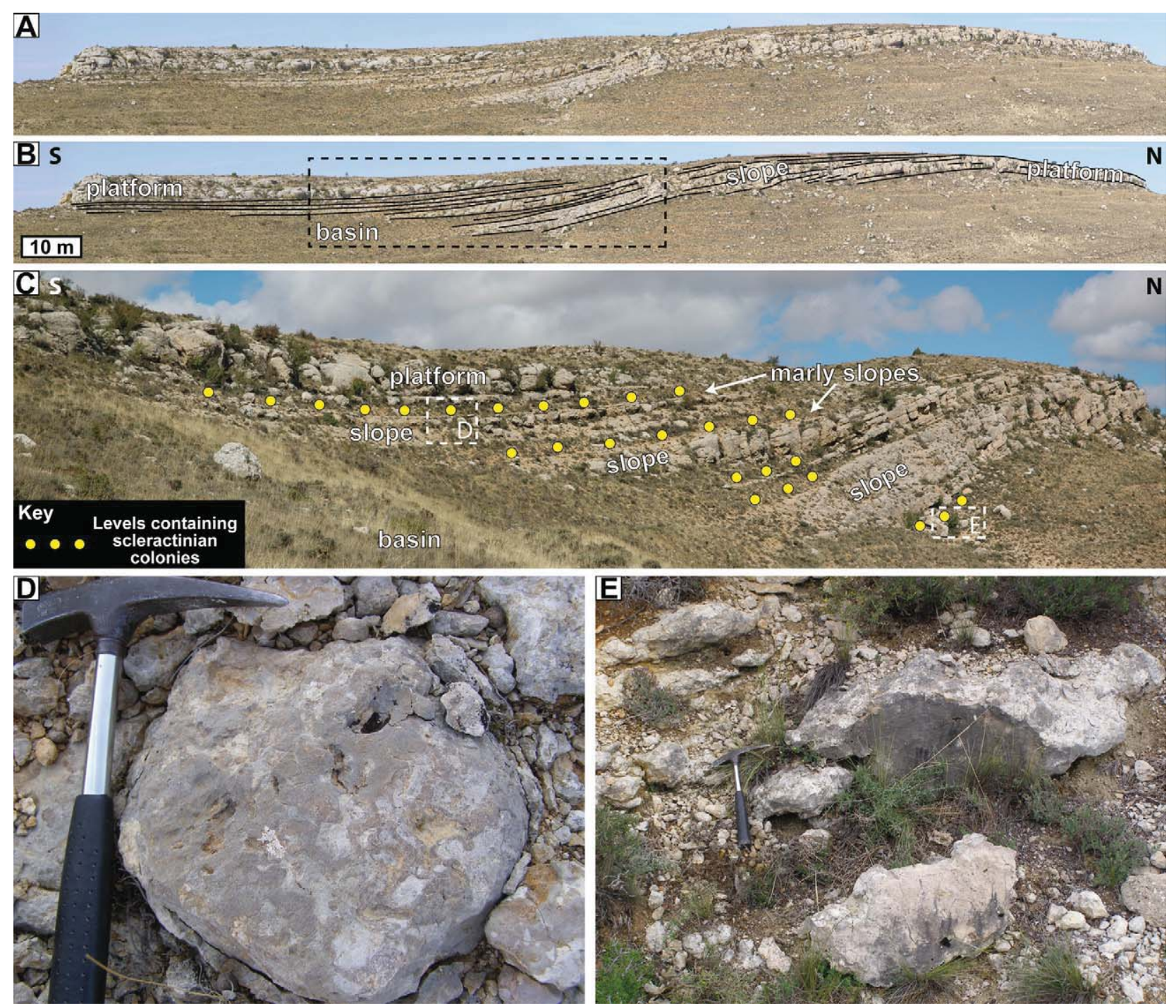

Fig. 3. A, general view of the platform-to-basin transition at the El Morrón locality. B, line-drawing of A and situation of the platform, slope and basin settings. The black-outlined square indicates the location of C. C, situation of Early Aptian marly slope environments rich in autochthonous coral colonies. White-outlined squares point to the locations of D and E. D, detail of a massive coral colony. E, metre-sized coral bioherm formed by massive colonies. 


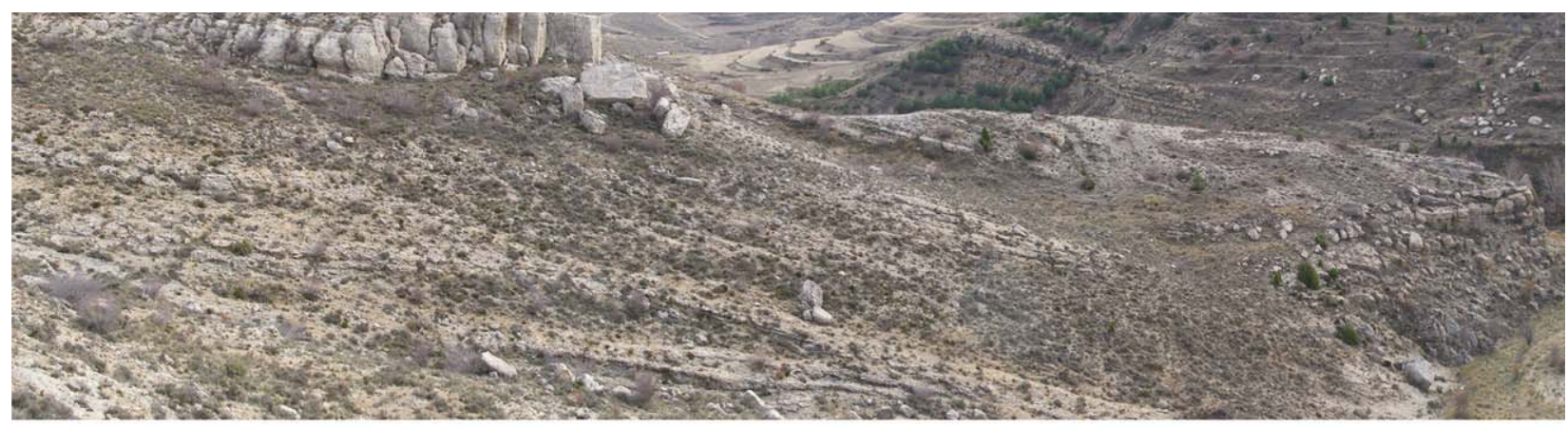

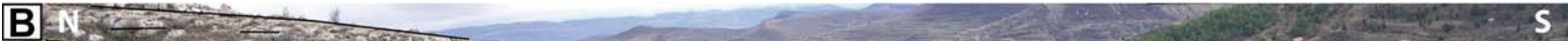
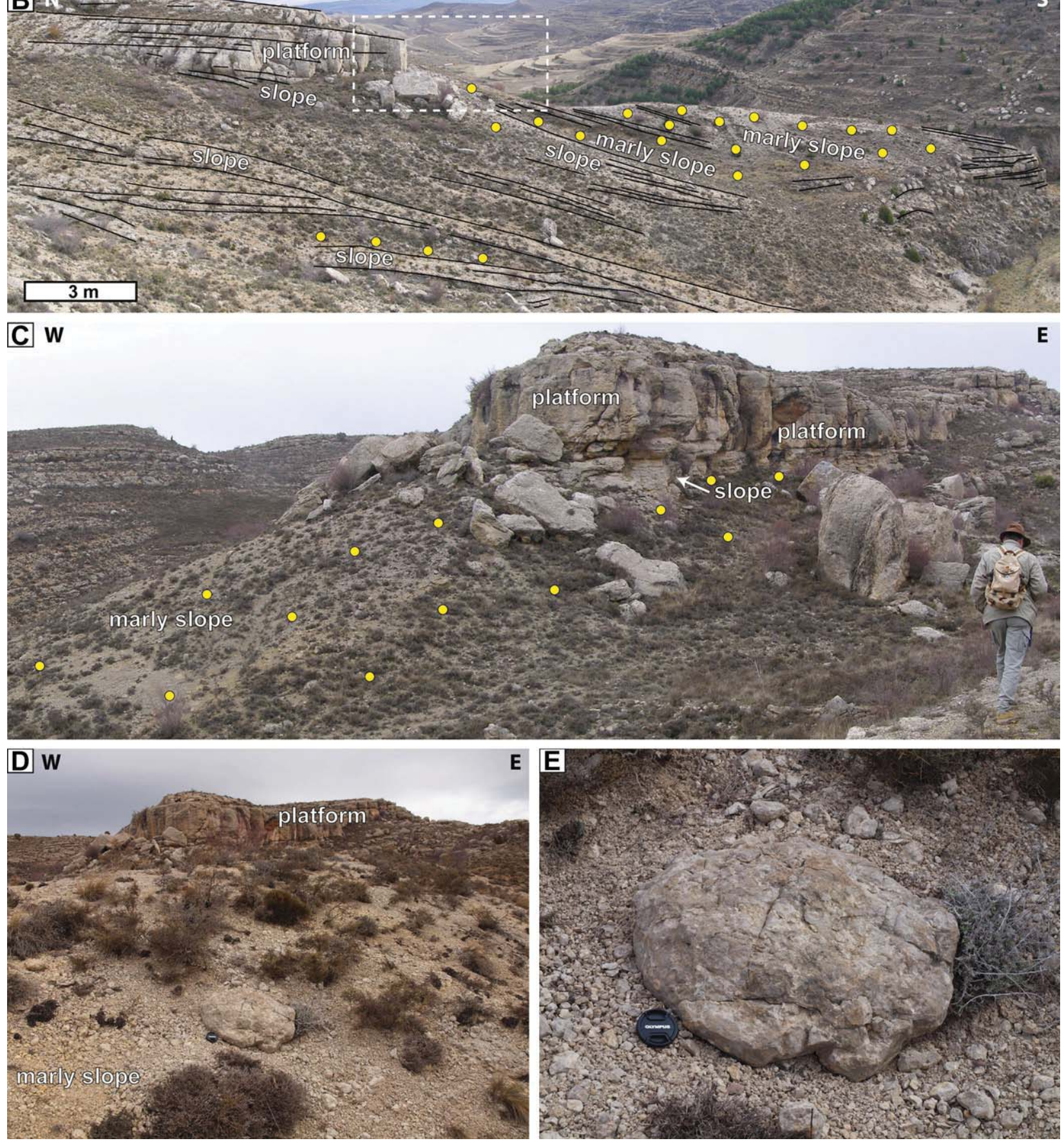

Fig. 4. A, photomosaic of Early Aptian platform-to-slope transition at the Las Mingachas locality, looking east. B, line-drawing of A and situation of the platform and slope settings. Note that the autochthonous scleractianian colonies analysed flourished in marly slope environments; see Fig. 3 C for key. The white-outlined square shows the location of C. C, platform-to-slope transition with marly slope sediments rich in autochthonous coral colonies, person $=1.77 \mathrm{~m}$. D, detail of an isolated flattened, dome-shaped colony in life position on a marly slope at Las Mingachas locality, camera cap $=5.8 \mathrm{~cm}$. E, close-up of the autochthonous colony displayed in Fig. $4 \mathrm{D}$, camera cap $=5.8 \mathrm{~cm}$. 

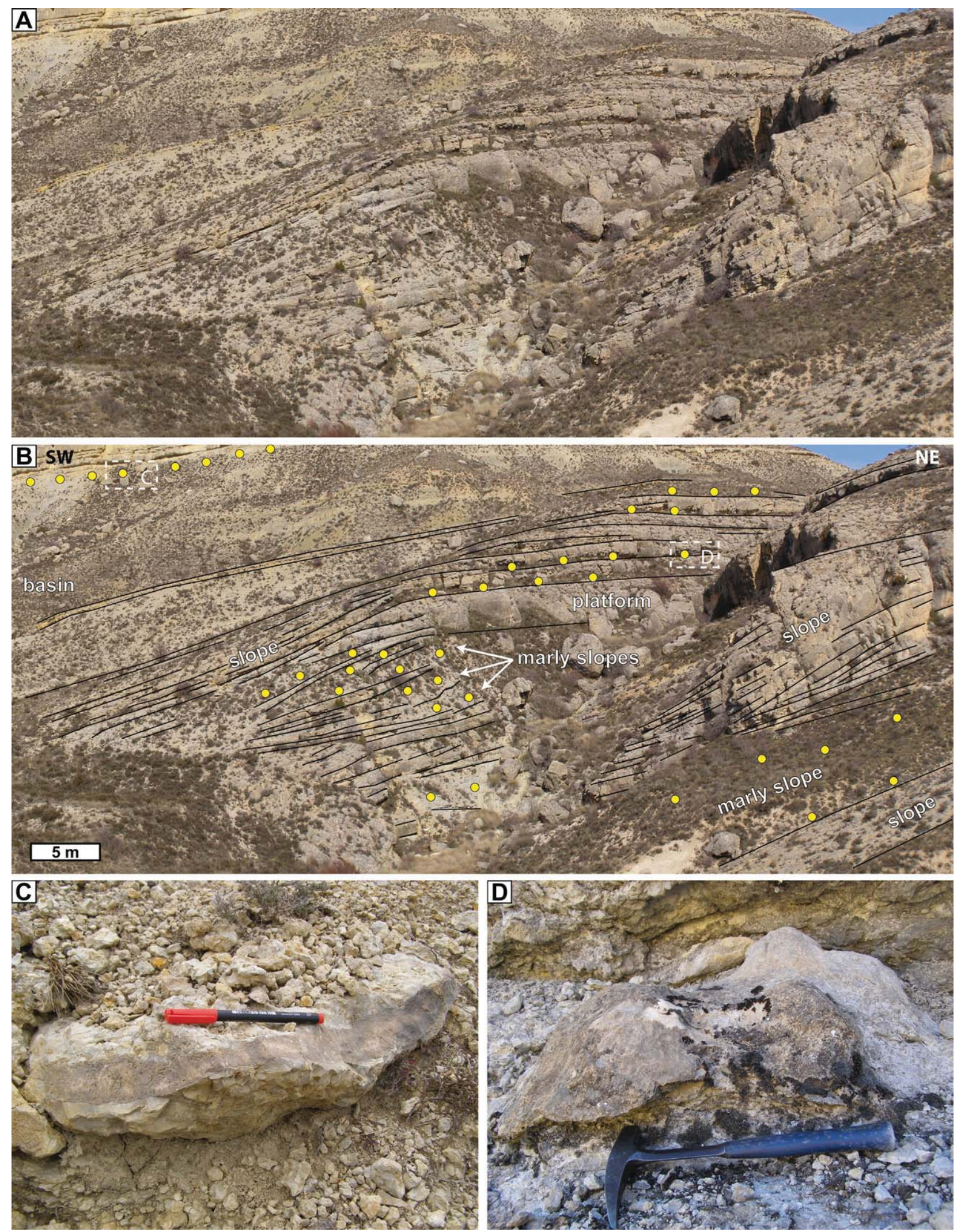

Fig. 5. A, outcrop-scale view of platform-to-slope transitions at the Las Mingachas locality, looking west. B, line-drawing of A and situation of the platform and slope settings. Note the occurrence of autochthonous scleractinian colonies in marly slope environments; see Fig. $3 \mathrm{C}$ for key. White-outlined squares point to the locations of C and D. C, detail of a platy coral embedded in marls, Late Aptian, pen $=14.4 \mathrm{~cm}$. D, detail of an isolated domal colony preserved on top of a limestone bed, Early Aptian, hammer $=32 \mathrm{~cm}$. 
centimetre- to metre-thick, light grey, nodular-bedded floatstones and rudstones with rudist, coral, and other skeletal fragments (Figs. 3-5). The floatstone and rudstone beds display channel-fill geometries, erosive surfaces and slump scars. They are interpreted as being composed of material that was shed from the platform top and moved down-slope in channels and as debris sheets (Bover-Arnal et al., 2009). Autochthonous scleractinian colonies also occur within these deposits, indicating that sediment shedding was active only periodically, and/or that an active debris fan covered only part of the slope and left other areas untouched for long enough to allow corals to grow.

The corals colonized the slope surfaces over distances of more than $10 \mathrm{~m}$ and at depths of less than $30 \mathrm{~m}$ with respect to the platform top but did not settle in basin settings (Fig. 3A-C). These
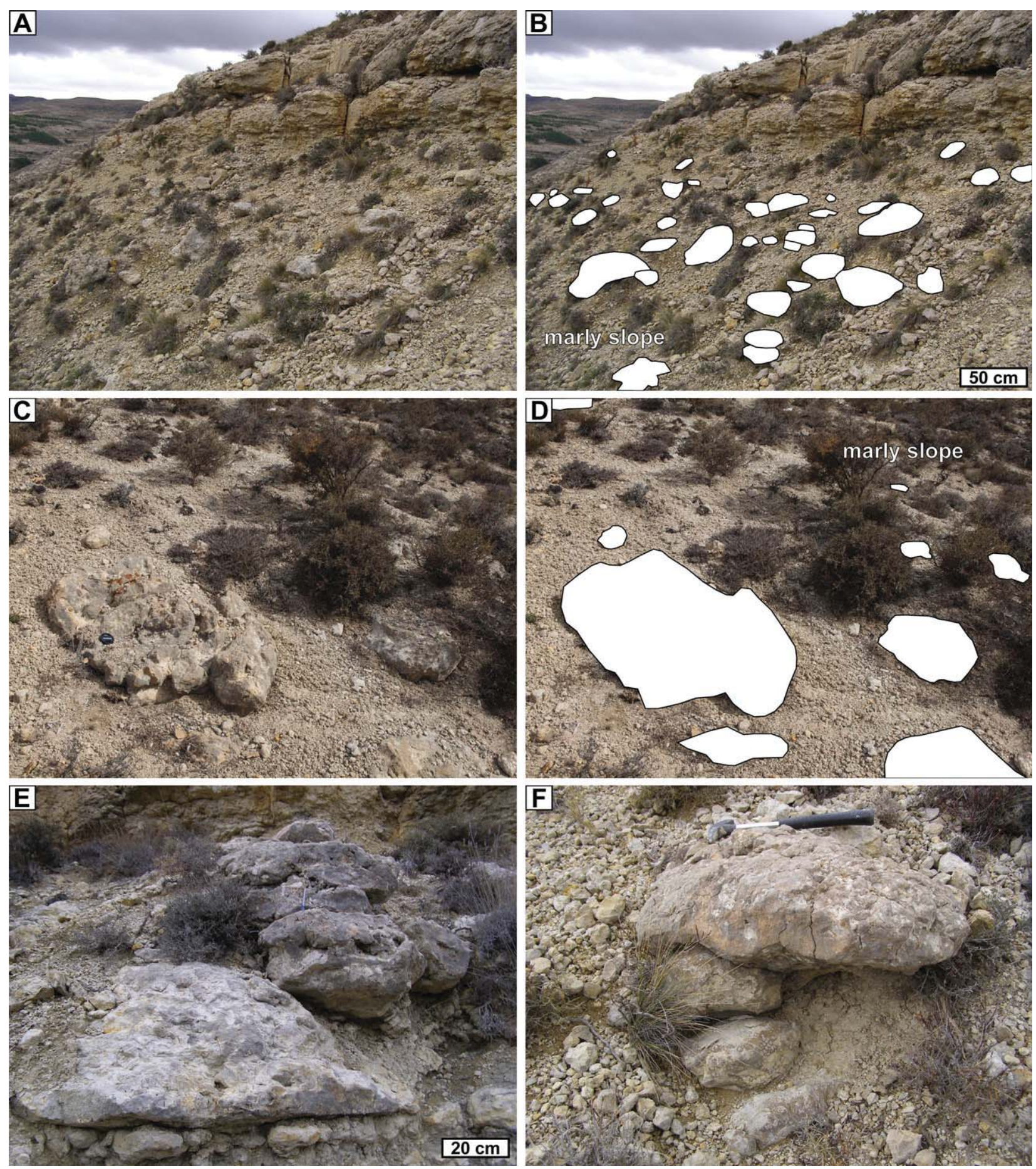

Fig. 6. A, outcrop-scale view of a marly interval exhibiting a relatively high-density population of autochthonous scleractinian colonies, Late Aptian, Las Mingachas locality. Note the continuous unbound growth fabric exhibited by the corals. B, interpretation of A. The situation of the autochthonous coral colonies is indicated with white areas. C, outcrop-scale view of a marly slope setting containing autochthonous massive scleractinian colonies, Early Aptian, Las Mingachas locality. Note the continuous sparse fabric displayed by the corals, camera cap $=5.8 \mathrm{~cm}$. D, interpretation of C. The situation of the autochthonous coral colonies is indicated by white areas. E, detail of irregular massive coral colonies, which fuse into a metre-sized bioherm in a marly slope environment, Late Aptian, Barranco de las Corralizas locality. F, close-up view of four irregular massive colonies, which grew one on top of the other in a marly slope setting, Late Aptian, Barranco de las Corralizas locality, hammer $=32 \mathrm{~cm}$. 
faunas developed principally as isolated colonies on marly and platform-derived skeletal lime mud substrates (Figs. 3C, 4D, E, 5C, D, 6A-D). However, specimens attached to hard substrates provided by clustered rudists in life position (Polyconites hadriani; Skelton et al., 2010) or by dead coral colonies also occur (Fig. 6E, F), on occasions giving rise to metre-sized bioherms (Figs. 3E and 6E).
Overturned or damaged colonies or coral rubble were not observed. The colonies exhibit massive (Figs. 3D, E, 4D, E, 6C-F, 7A, B), platy (Fig. 5C), fragile-branching (Fig. 7C, D), domal (Figs. 5D and 7E), and columnar (Fig. 7F) morphologies. Irregular massive growth forms with relatively high width-to-height ratios and dome-shaped morphologies are the most prevalent. The sizes of the colonies
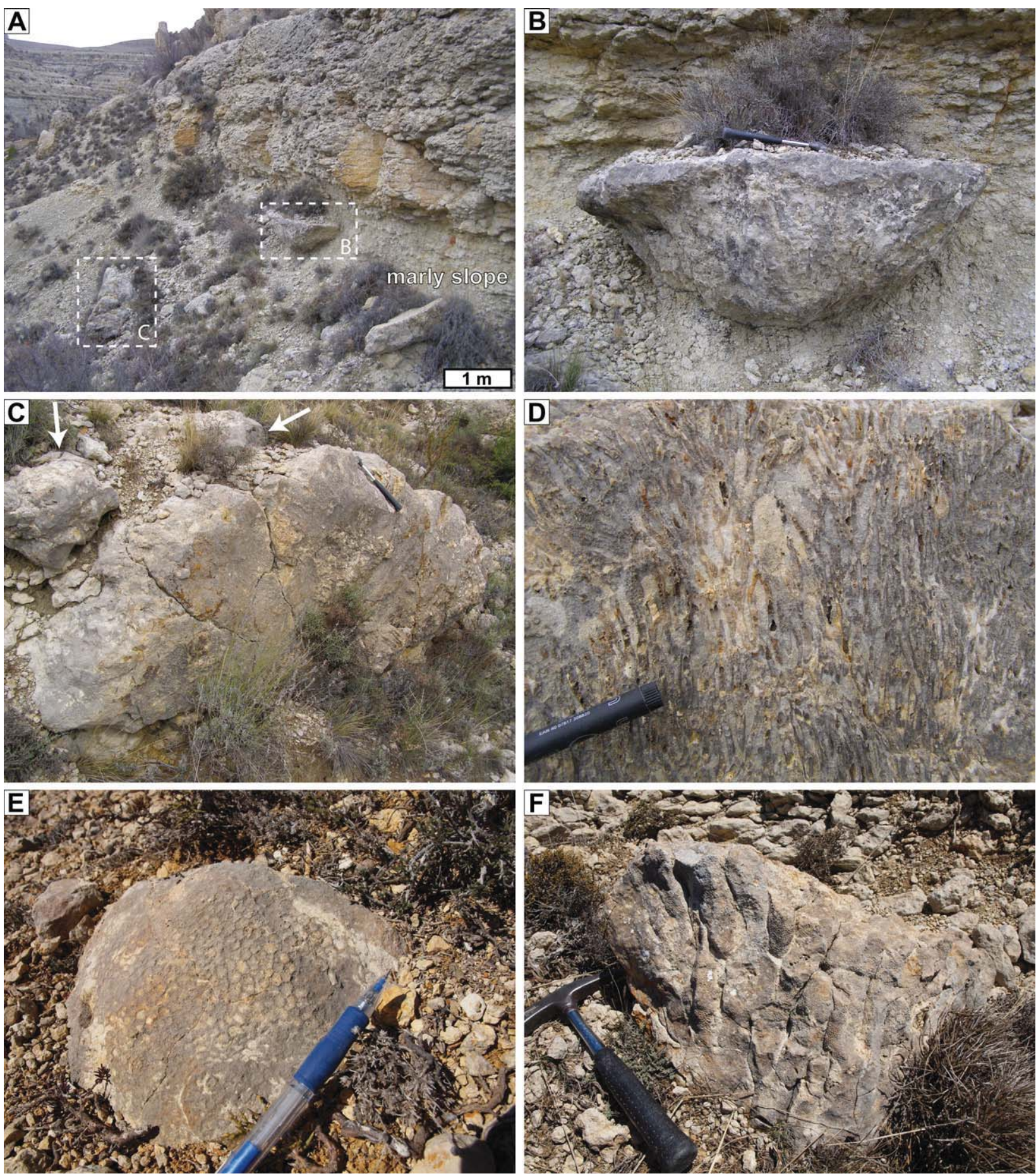

Fig. 7. A, outcrop-scale view of a marly interval rich in autochthonous scleractinian colonies, Late Aptian, Barranco de las Corralizas locality. White-outlined squares point out the locations of B and C. B, close-up view of a large isolated massive colony embedded in slope marls. Note the bowl-like morphology, which is probably the result of constratal growth. C, photograph of a large delicate-branching coral colony embedded in slope marls, Late Aptian, Barranco de las Corralizas locality. Arrows point to two smaller irregular massive colonies, which grew attached to the branching colony below, hammer $=32 \mathrm{~cm}$. D, close-up view of the delicate-branching colony illustrated in C, visible part of pen $=5.2 \mathrm{~cm}$. E, detail of a small dome-shaped colony exhibiting well-visible corallites, Late Aptian, Barranco de la Canal locality, visible part of pen $=11.2 \mathrm{~cm}$. F, photograph of a small columnar scleractinian colony, Late Aptian, Barranco de la Canal locality, hammer $=32 \mathrm{~cm}$. 
range between $4 \mathrm{~cm}$ and $2.3 \mathrm{~m}$ in width and between $2 \mathrm{~cm}$ and $1.2 \mathrm{~m}$ in height, but the most are within the range of $15 \mathrm{~cm}$ to $1 \mathrm{~m}$ in width and $5-50 \mathrm{~cm}$ in height (Figs. 3D, E, 4E, 5C, D, 6, 7, 8A). The larger colonies correspond to fragile-branching, domal and massive forms. The largest colony recognized is illustrated in Fig. 7C. A cerioid calicular arrangement is the most frequent type of coral colony integration (Figs. 9A-D, 10D, H, 11A-C, E-G). However, other corallite integration levels such as phaceloid (Fig. 9E, F, I-K), plocoid (Figs. 9G, H, 10Q R), hydnophoroid (Figs. 9M-O, 10A-C, E-G), astreoid (Figs. 10I, J, P, S, T, 11D, H-L), meandroid (Fig. 9L, $\mathrm{P}-\mathrm{T}$ ) and thamnasterioid (Fig. 10K-O) are also common.

The loose and unbound growth fabric exhibited by the coral colonies is relatively continuous and uniform (basically dominated by massive and domal forms), with a low (coral skeletal volume $5 \%$ ) to medium (coral skeletal volume 20\%) degree of development (Fig. 6A-D; see Insalaco, 1998). Nearly all the scleractinian colonies surveyed had a superstratal growth (sensu Gili et al., 1995) (Figs. 3D, E, 4E, 5C, D, 6, 7C, E, F, 8A). This is implied by the relatively high width-to-height ratios and by bioerosional traces that affect the entire colony surface. However, a small number of specimens experienced at least a partial constratal growth as indicated by morphologies such as bowl-like forms (Fig. 7B). No differences in coral community structure were recognized either along the slope profile or between the Early and Late Aptian faunas.
Bioerosional structures are abundant in particular stratigraphic intervals where the corals are covered by marls. The bioerosional patterns mainly correspond to the ichnogenus Gastrochaenolites (Fig. 8). Diameters of the rounded and oval cavities produced by lithophagid bivalves are up to $5 \mathrm{~cm}$ but mostly range between 1 and $3 \mathrm{~cm}$. In situ valves of the bivalves are frequently preserved inside the borings (Fig. 8C). Coral growth around Gastrochaenolites has been observed in four colonies. Also present are $\mathrm{mm}$ - to $\mathrm{cm}$-sized elongated bioerosional structures (Fig. 8D) similar to those produced today by sipunculan worms (Klein et al., 1991; Scoffin and Bradshaw, 2000). Traces of boring sponges (ichnogenus Entobia) are rare and were identified in only one colony. Corals not affected by bioerosion are common as well (Fig. 7C-F) and mostly occur in specific stratigraphic levels that are overlain by deposits shed from the platform top.

Accompanying macrofossils found in the slope marls and marly limestones containing colonial corals are bouquets of the rudist Polyconites hadriani (Skelton et al., 2010), oysters, other bivalves, gastropods, and irregular echinoids, all of them mainly preserved in life position. More rarely, ammonoids occur. Organisms such as red algae, Lithocodium aggregatum or microbes encrusting the coral surfaces were not recognized either in the outcrop or in thinsection. Solitary corals have not been found in the coral-bearing slope settings but are present in basinal environments (BoverArnal et al., 2010, 2011b).
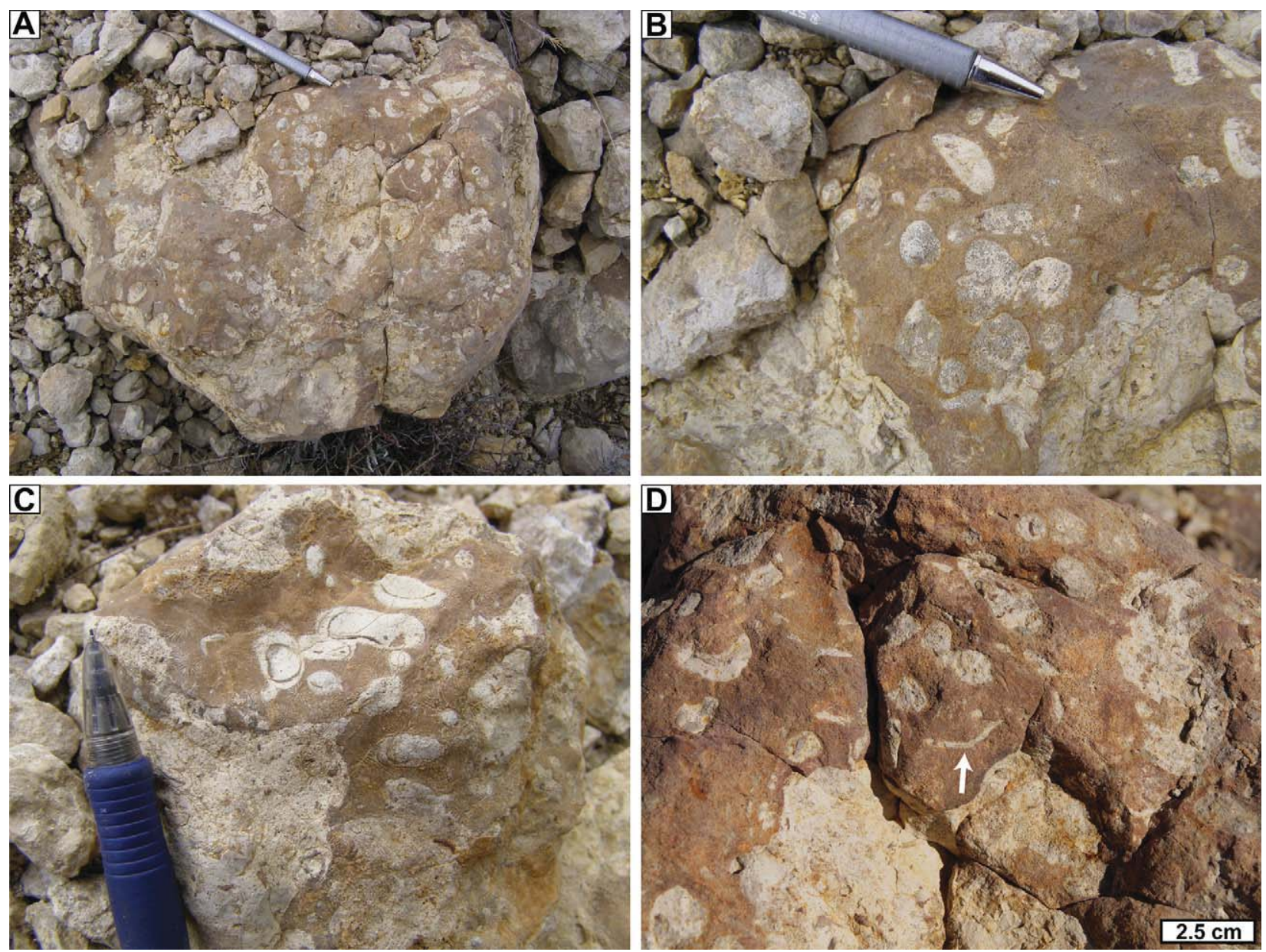

Fig. 8. A, photograph of a highly-bioeroded irregular massive colony, Late Aptian, Barranco de las Corralizas locality. Note the abundant Gastrochaenolites trace fossils, visible part of pen $=10.5 \mathrm{~cm}$. B, close-up of A displaying Gastrochaenolites, visible part of pen: $6.4 \mathrm{~cm}$. C, close-up of an irregular massive colony displaying Gastrochaenolites, which exhibit in situ valves of boring bivalves, Late Aptian, Villarroya de los Pinares locality, visible part of pen $=5 \mathrm{~cm}$. D, close-up of A showing an elongated trace probably produced by a bioeroding worm (white arrow). 

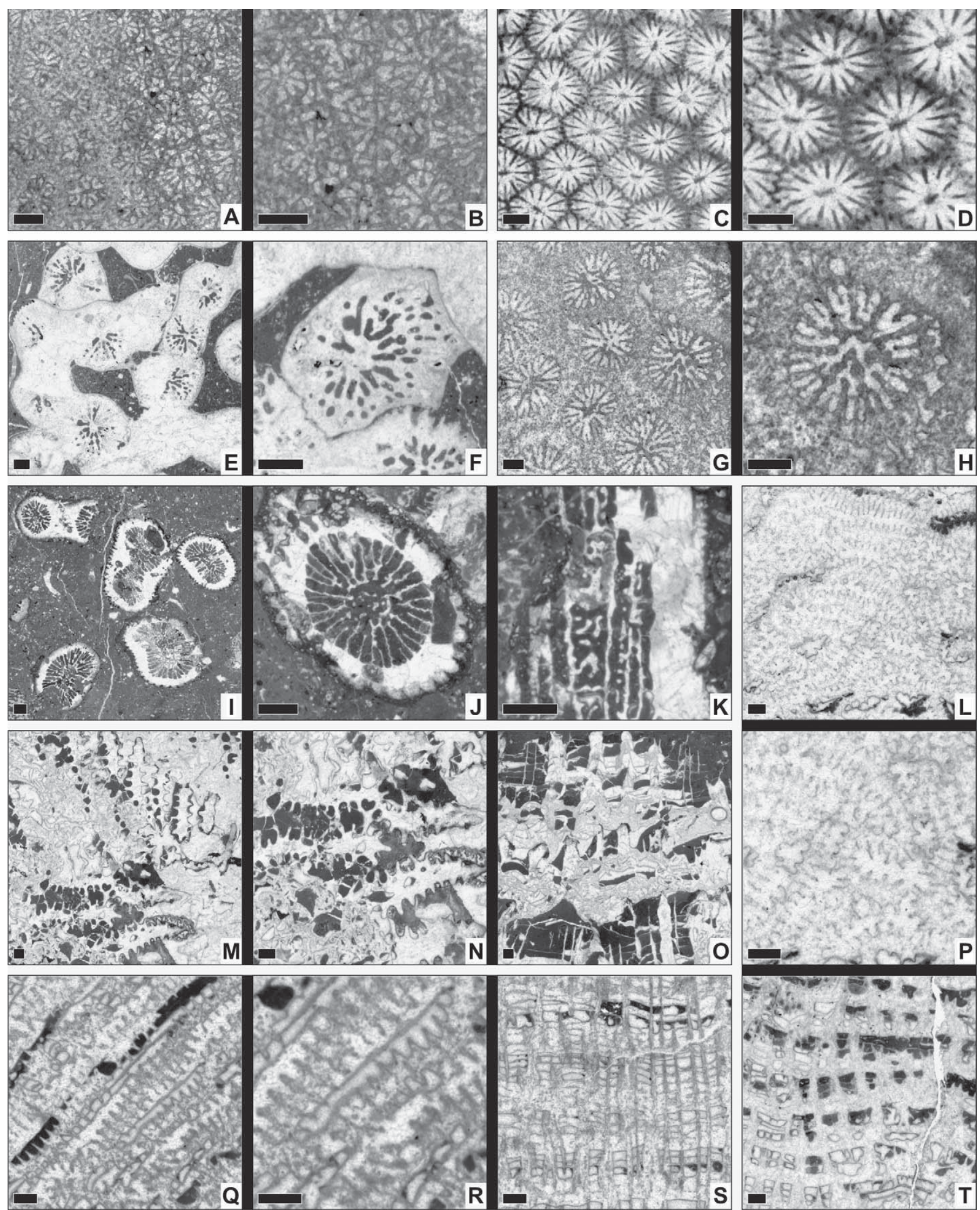

Fig. 9. Photomicrographs of the corals identified. A, B, Agrostyliastraea sp. (78455). C, D, Stelidioseris actinastrae (Turnšek and Mihajlovic, 1981) (78449). E, F, Actinastraeopsis catalaunica (d'Angelis d'Ossat, 1905) (78445). G, H, Placocolumastrea affinis (Hackemesser, 1936) (78480). I-K, Procladocora sp. (74604). L, Diplogyra sp. (78441). M-O, Eohydnophora picteti (Koby, 1896) (74615). P, T, Diplogyra sp. (78441). Q-S, Diplogyra cf. minima Morycowa and Marcopoulou-Diacantoni, 1997 (78481). Black frames group photomicrographs of the same species. Scale bar represents $1 \mathrm{~mm}$. 

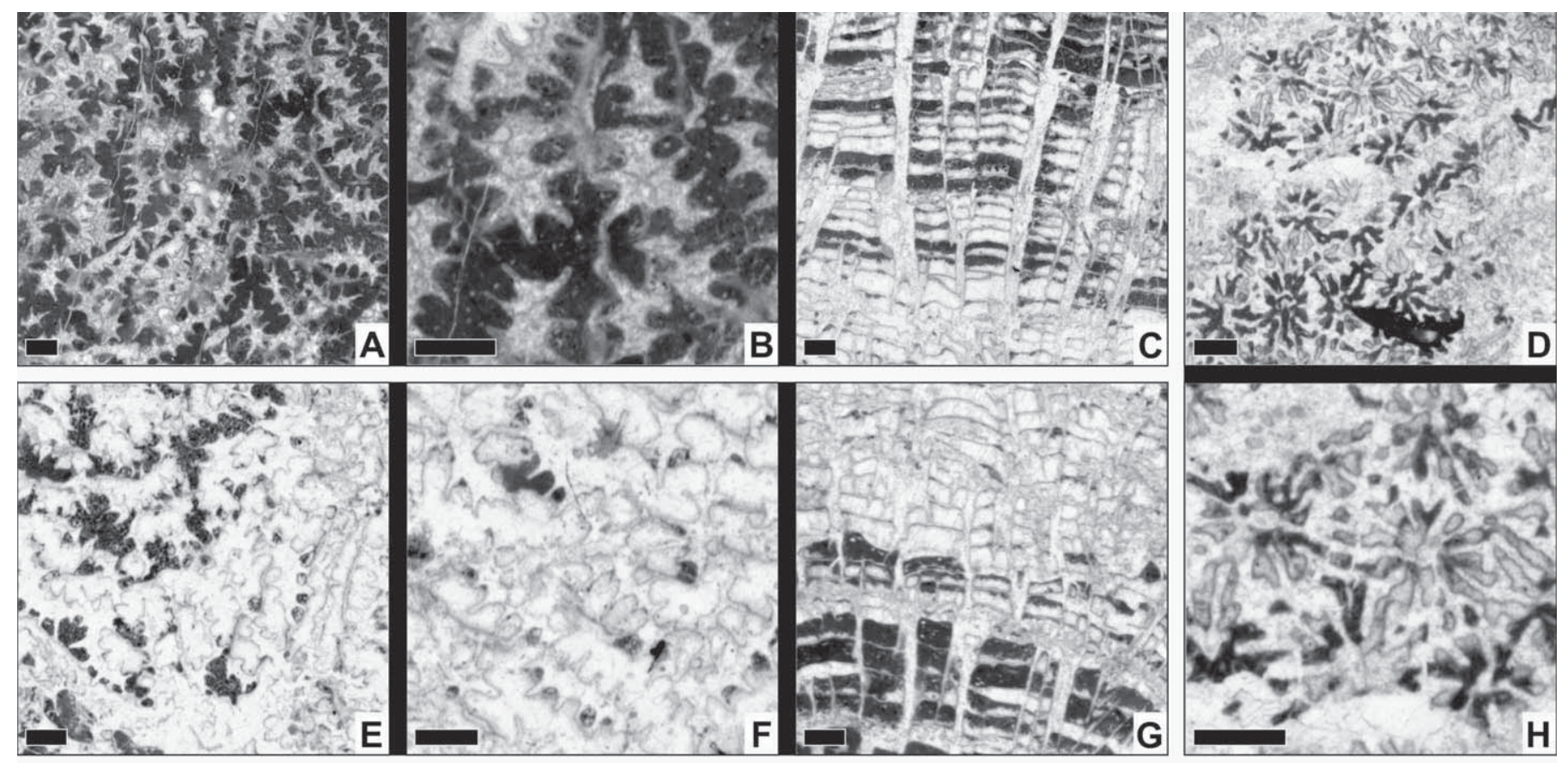

Tol

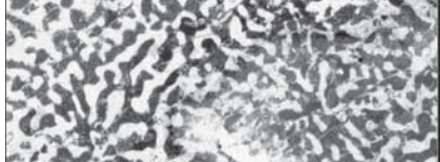
one

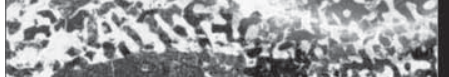
$52,+3,2$ th

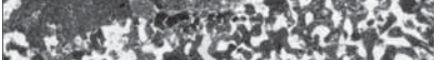
cion

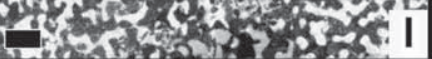
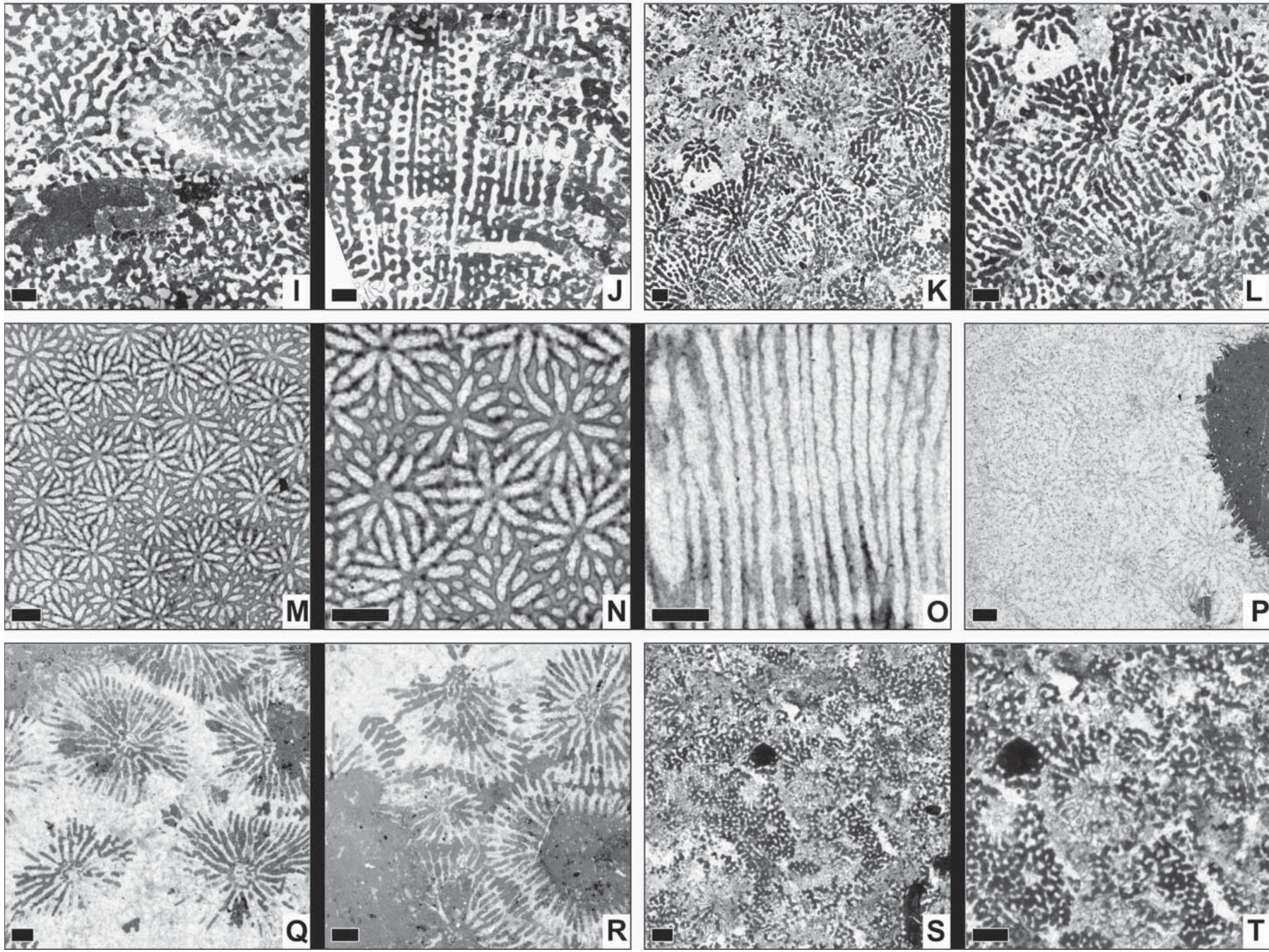

Fig. 10. Photomicrographs of the corals identified. A-C, Eohydnophora tenuis (Toula, 1878) (74610). D, H. Holocoenia bendukidzeae (Sikharulidze, 1972) (74632). E-G, Eohydnophora tosaensis Yabe and Eguchi, 1936 (74607). I, J, Camptodocis sp. (74640). K, L, Camptodocis cf. tottoni (Wells, 1935) (74631). M-O, Mesomorpha cf. mammillata (Reuss, 1854) (78450). P, Complexastrea sp. (78485). Q, R, Ovalastrea sp. (78470). S, T, Polyphylloseris simondsi (Wells, 1932) (74635). Black frames group photomicrographs of the same species. Scale bar represents $1 \mathrm{~mm}$. 

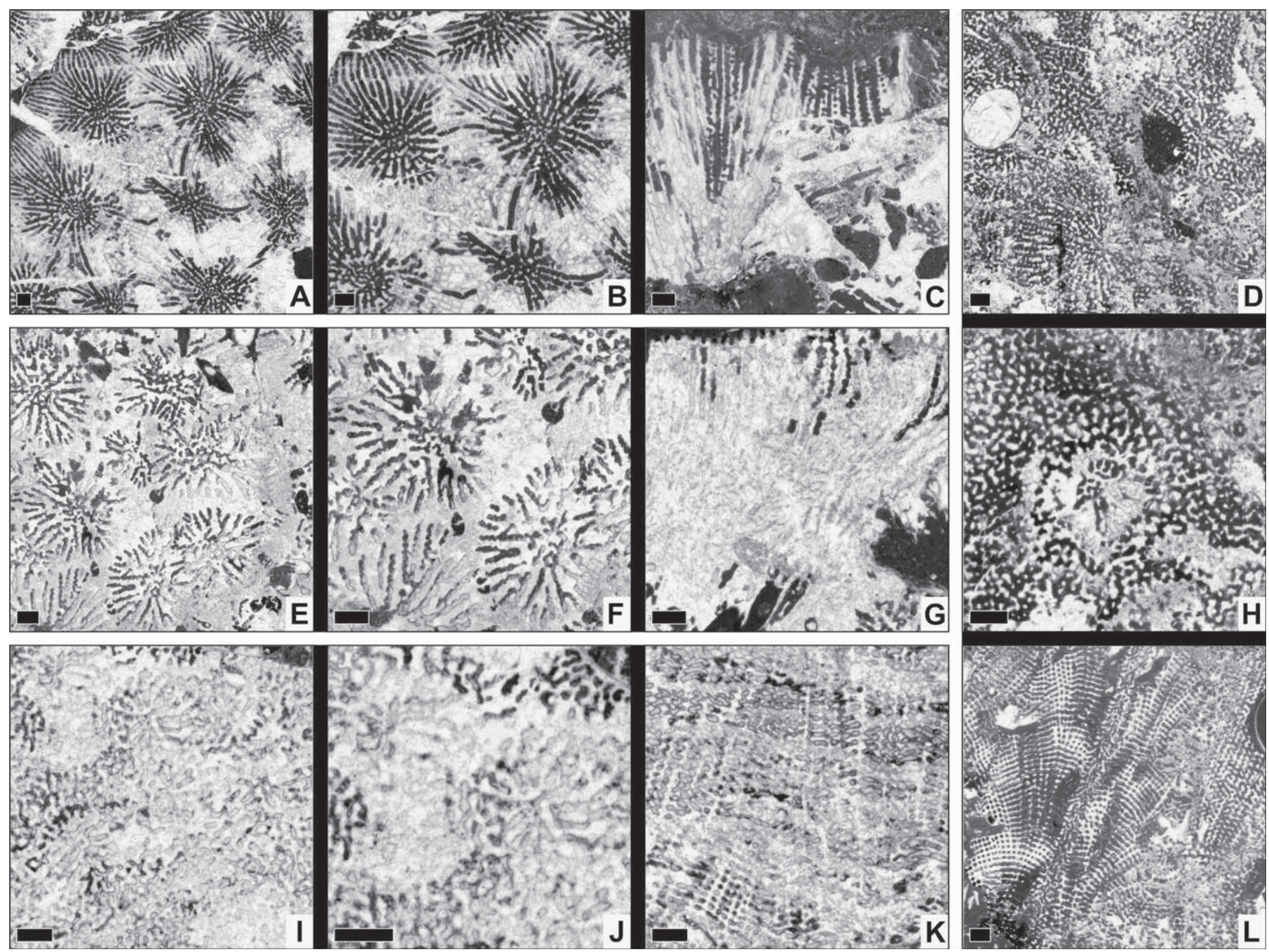

Fig. 11. Photomicrographs of the corals identified. A-C, Thalamocaeniopsis ouenzensis Alloiteau, 1953 (78486). D, H, L, Polyphylloseris cf. kobyi (Prever, 1909) (74616). E-G, Thalamocaeniopsis sp. (74621). I-K, Eocomoseris raueni Melnikova et al., 1993 (74611). Black frames group photomicrographs of the same species. Scale bar represents $1 \mathrm{~mm}$.

\section{Systematic palaeontology}

The coral fauna has a comparatively low diversity and consists for the larger part of very common and well-known species. Synonymy lists and descriptions are therefore omitted. Systematically measured dimensions are provided to allow comparison with material described elsewhere (all values in $\mathrm{mm}$ unless otherwise stated). The type material of all species presented here was available for study by HL. Distribution data of the species come from comparison with specimens in the World Wide Fossil Coral Database with associated sample and image database (with 18,000 specimens, 7200 illustrated), located in the Estación Regional de Noroeste, Sonora, Mexico.

The following abbreviations are used to describe the dimensions of the corals: c max, larger outer calicular diameter; c min, smaller outer calicular diameter; c, calicular outer diameter; ccd, distance between calicular centres; $\mathrm{cl}$ max, large lumen diameter; $\mathrm{cl}$ min, small lumen diameter; cl, lumen diameter; crd, distance of calicular series; crw, width of calicular series; md, distance between monticules in a hydnophoroid colony; s, number of radial elements in adult calices; sd, density of radial elements; sdt, density of trabeculae; sk, number of radial elements which reach the columella.
The following abbreviations are used for the numerical dimensions of the corals: $n$, number of measurements; min-max, lowest and highest measured value; $\mu$, arithmetic mean (average); $s$, standard deviation; $v$, coefficient of variation according to Pearson (1926); $\mu \pm s$, first interval.

Suborder Archeocaeniina Alloiteau, 1952

Family Actinastraeidae Alloiteau, 1952

Genus Agrostyliastraea Morycowa and Marcopoulou-Diacantoni, 2002

Agrostyliastraea sp.

Fig. 9A, B

Material. MGSB 78455; 2 thin-sections.

Dimensions

\begin{tabular}{lllllll}
\hline (78455) & $n$ & $\min -\max$ & $\mu$ & $s$ & $v$ & $\mu \pm s$ \\
\hline cl min & 45 & $1.032-1.850$ & 1.435 & 0.214 & 14.9 & $1.22-1.64$ \\
cl max & 45 & $1.251-2.652$ & 1.833 & 0.369 & 20.1 & $1.46-2.20$ \\
ccd & 50 & $1.311-2.179$ & 1.716 & 0.245 & 14.2 & $1.47-1.96$ \\
$\mathrm{~s}$ & 24 & & & & & \\
\hline
\end{tabular}


Remark. The sample is distinguished from the type (and only) species by its much smaller dimensions.

Occurrence. Late Aptian (Epicheloniceras martini Zone), Barranco de las Corralizas.

Genus Stelidioseris Tomes, 1893

Stelidioseris actinastrae (Turnšek and Mihajlovic, 1981)

Fig. 9C. D

Material. MGSB 74634, 78436, 78437, 78438, 78440, 78442, 78449, 78454, 78462, 78467, 78469, 78482, 78488, 78489; 24 thinsections.

Dimensions

\begin{tabular}{lllllll}
\hline (78449) & $n$ & $\min -\max$ & $\mu$ & $s$ & $v$ & $\mu \pm s$ \\
\hline cl min & 40 & $1.395-2.141$ & 1.717 & 0.199 & 11.5 & $1.51-1.91$ \\
cl max & 40 & $1.725-2.577$ & 2.106 & 0.237 & 11.2 & $1.86-2.34$ \\
ccd & 40 & $1.461-2.296$ & 1.917 & 0.237 & 12.3 & $1.68-2.15$ \\
$\mathrm{~s}$ & 24 & & & & & \\
\hline
\end{tabular}

Occurrence. Early Aptian (Dufrenoyia furcata Zone), El Morrón; Late Aptian (Epicheloniceras martini Zone), Cabezo de las Hoyas, Barranco de la Canal and Barranco de las Corralizas.

Occurrence elsewhere. Barremian-Late Cenomanian worldwide.

Suborder Faviina Vaughan and Wells, 1943

Family Cladocoridae Milne-Edwards, 1857

Genus Actinastraeopsis Sikharulidze, 1977

Actinastraeopsis catalaunica (d'Angelis d'Ossat, 1905)

Fig. 9E, F

Material. MGSB 74605, 78445; 4 thin-sections.

Dimensions

\begin{tabular}{lllllll}
\hline (78445) & $n$ & $\min -\max$ & $\mu$ & $s$ & $v$ & $\mu \pm s$ \\
\hline cl min & 12 & $1.674-2.507$ & 2.055 & 0.277 & 13.5 & $1.77-2.33$ \\
cl max & 12 & $2.225-3.187$ & 2.650 & 0.345 & 13.0 & $2.30-2.99$ \\
c min & 12 & $2.376-3.474$ & 2.974 & 0.329 & 11.0 & $2.64-3.30$ \\
c max & 12 & $2.775-4.245$ & 3.597 & 0.475 & 13.2 & $3.12-4.07$ \\
s & 48 & & & & & \\
\hline
\end{tabular}

Occurrence. Early Aptian (Dufrenoyia furcata Zone), La Serna; Late Aptian (Epicheloniceras martini Zone), Barranco de la Canal.

Occurrence elsewhere. Aptian-Early Albian of the western Tethys and the Caribbean.

Genus Procladocora Alloiteau, 1952

Procladocora sp.

Fig. 9I-K

Material. MGSB 74600, 74601, 74602, 74604; 8 thin-sections.
Dimensions

\begin{tabular}{lllllll}
\hline (74604) & $n$ & $\min -\max$ & $\mu$ & $s$ & $v$ & $\mu \pm s$ \\
\hline c min & 8 & $3.003-4.653$ & 3.599 & 0.539 & 14.9 & $3.06-4.13$ \\
c max & 8 & $3.281-6.253$ & 4.607 & 1.042 & 22.6 & $3.56-5.64$ \\
cl min & 8 & $1.853-3.462$ & 2.540 & 0.507 & 19.9 & $2.03-3.04$ \\
cl max & 8 & $2.338-4.708$ & 3.436 & 0.795 & 23.1 & $2.64-4.23$ \\
s & 48 & & & & & \\
\hline
\end{tabular}

Occurrence. Early Aptian (Dufrenoyia furcata Zone), La Serna.

Family Columastraeidae Alloiteau, 1952

Genus Placocolumastrea Reig Oriol, 1989

Placocolumastrea affinis (Hackemesser, 1936)

Fig. 9G, H

Material. MGSB 74606, 78480; 5 thin-sections.

Dimensions

\begin{tabular}{lllllll}
\hline (78480) & $n$ & $\min -\max$ & $\mu$ & $s$ & $v$ & $\mu \pm s$ \\
\hline $\mathrm{cl}$ & 30 & $2.362-3.088$ & 2.767 & 0.174 & 6.3 & $2.59-2.94$ \\
$\mathrm{ccd}$ & 30 & $2.655-4.192$ & 3.356 & 0.382 & 11.4 & $2.97-3.73$ \\
$\mathrm{~s}$ & 24 & & & & & \\
\hline
\end{tabular}

Occurrence. Early Aptian (Dufrenoyia furcata Zone), La Serna; Late Aptian (Epicheloniceras martini Zone), Barranco de las Corralizas.

Occurrence elsewhere. Barremian-Early Cenomanian of the Tethys, the western Atlantic and the European Boreal region.

Family Eugyridae Duncan, 1884

Genus Diplogyra Eguchi, 1936

Diplogyra cf. minima Morycowa and Marcopoulou-Diacantoni, 1997

Fig. 9Q-S

Material. MGSB 78481, 78484; 4 thin-sections.

Dimensions

\begin{tabular}{lllllll}
\hline$(78481)$ & $n$ & $\min -\max$ & $\mu$ & $s$ & $v$ & $\mu \pm s$ \\
\hline crw & 10 & $0.887-1.277$ & 1.095 & 0.132 & 12.0 & $0.96-1.22$ \\
crd & 10 & $1.356-2.040$ & 1.692 & 0.222 & 13.1 & $1.47-1.91$ \\
sd & $13 / 5 \mathrm{~mm}$ & & & & & \\
\hline
\end{tabular}

Remark. The material differs from Diplogyra minima by having a higher density of septa.

Occurrence. Late Aptian (Epicheloniceras martini Zone), Barranco de las Corralizas.

Diplogyra sp.

Fig. 9L, P, T

Material. MGSB 78441; 2 thin-sections. 
Dimensions

\begin{tabular}{lllllll}
\hline (78441) & $n$ & $\min -\max$ & $\mu$ & $s$ & $v$ & $\mu \pm s$ \\
\hline crw & 20 & $0.581-0.926$ & 0.776 & 0.093 & 12.0 & $0.68-0.87$ \\
crd & 20 & $1.137-1.666$ & 1.403 & 0.152 & 10.8 & $1.25-1.55$ \\
sd & $16 / 5 \mathrm{~mm}$ & & & & & \\
\hline
\end{tabular}

Remark. The dimensions of the material are very small and do not compare with an existing species.

Occurrence. Late Aptian (Epicheloniceras martini Zone), Cabezo de las Hoyas.

Genus Eohydnophora Yabe and Eguchi, 1936

Remarks. Eohydnophora currently encompasses all Early Cretaceous faviid hydnophoroid corals showing conical as well as polygonal monticules. The possible separation of forms with conical monticules has been discussed by Löser (2010b).

Eohydnophora picteti (Koby, 1896)

Fig. 9M-O

Material. MGSB 74615, 74625; 4 thin-sections.

Dimensions

\begin{tabular}{lllllll}
\hline$(74615)$ & $n$ & $\min -\max$ & $\mu$ & $s$ & $v$ & $\mu \pm s$ \\
\hline $\begin{array}{l}\mathrm{md} \\
\mathrm{sd}\end{array}$ & 10 & $1.673-2.552$ & 2.180 & 0.263 & 12.1 & $1.91-2.44$ \\
\hline
\end{tabular}

Remark. Eohydnophora picteti is a form with conical monticules.

Occurrence. Early Aptian (Dufrenoyia furcata Zone), Las Mingachas.

Occurrence elsewhere. Hauterivian-Early Cenomanian worldwide.

Eohydnophora tenuis (Toula, 1878)

Fig. 10A-C

Material. MGSB 74610, 74612, 78452, 78478; 9 thin-sections.

Dimensions

\begin{tabular}{lllllll}
\hline$(74610)$ & $n$ & $\min -\max$ & $\mu$ & $s$ & $v$ & $\mu \pm s$ \\
\hline $\mathrm{md}$ & 30 & $1.001-1.553$ & 1.249 & 0.154 & 12.3 & $1.09-1.40$ \\
$\mathrm{sd}$ & $6 / 2 \mathrm{~mm}$ & & & & & \\
\hline
\end{tabular}

Remark. Eohydnophora tenuis is a form with polygonal monticules.

Occurrence. Early Aptian (Dufrenoyia furcata Zone), La Serna; Late Aptian (Epicheloniceras martini Zone), Barranco de las Corralizas and Villarroya de los Pinares.

Occurrence elsewhere. Barremian-Aptian of the Tethys.

Eohydnophora tosaensis Yabe and Eguchi, 1936

Fig. 10E-G

Material. MGSB 74607, 74614, 74637; 6 thin-sections.
Dimensions

\begin{tabular}{lllllll}
\hline$(74614)$ & $n$ & $\min -\max$ & $\mu$ & $s$ & $v$ & $\mu \pm s$ \\
\hline $\begin{array}{l}\mathrm{md} \\
\mathrm{sd}\end{array}$ & 15 & $0.831-1.263$ & 1.031 & 0.137 & 13.3 & $0.89-1.16$ \\
\hline
\end{tabular}

Remark. Eohydnophora tosaensis is a form with polygonal monticules.

Occurrence. Early Aptian (Dufrenoyia furcata Zone), La Serna and El Morrón.

Occurrence elsewhere. Barremian-Aptian of the western Tethys and the western Pacific.

Family Montlivaltiidae Felix, 1900

Genus Complexastrea d'Orbigny, 1849

Complexastrea sp.

Fig. 10P

Material. MGSB 78448, 78485; 4 thin-sections.

Dimensions

\begin{tabular}{lllllll}
\hline (78485) & $n$ & $\min -\max$ & $\mu$ & $s$ & $v$ & $\mu \pm s$ \\
\hline $\mathrm{cl}$ & 10 & $3.362-4.946$ & 3.858 & 0.481 & 12.4 & $3.37-4.34$ \\
$\mathrm{ccd}$ & 20 & $3.343-6.381$ & 4.564 & 0.944 & 20.6 & $3.62-5.50$ \\
$\mathrm{~s}$ & $40-60$ & & & & & \\
$\mathrm{sd}$ & $8 / 2 \mathrm{~mm}$ & & & & & \\
\hline
\end{tabular}

Occurrence. Late Aptian (Epicheloniceras martini Zone), Barranco de la Canal and Barranco de las Corralizas.

Occurrence elsewhere. Early Aptian of the Tethys and western Atlantic.

Suborder Fungiina Verrill, 1868-1870

Family Haplaraeidae Vaughan and Wells, 1943

Genus Camptodocis Dietrich, 1926

Camptodocis sp.

Fig. 10I, J

Material. MGSB 74640; 1 thin-section.

Dimensions

\begin{tabular}{lllllll}
\hline (74640) & $n$ & $\min -\max$ & $\mu$ & $s$ & $v$ & $\mu \pm s$ \\
\hline $\mathrm{ccd}$ & 10 & $3.229-4.373$ & 3.812 & 0.368 & 9.6 & $3.44-4.18$ \\
$\mathrm{~s}$ & 40 & & & & & \\
$\mathrm{sd}$ & $10 / 5 \mathrm{~mm}$ & & & & & \\
\hline
\end{tabular}

Occurrence. Early Aptian (Dufrenoyia furcata Zone), El Morrón.

Occurrence elsewhere. Barremian of the western Tethys.

Camptodocis cf. tottoni (Wells, 1935)

Fig. 10K, L

Material. MGSB 74608, 74627, 74628B, 74629A, 74630, 74631, 74632C, 74633, 74636, 74638, 78435; 18 thin-sections. 
Dimensions

\begin{tabular}{lllllll}
\hline (74631) & $n$ & $\min -\max$ & $\mu$ & $s$ & $v$ & $\mu \pm s$ \\
\hline $\mathrm{ccd}$ & 30 & $3.520-4.792$ & 4.134 & 0.370 & 8.9 & $3.76-4.50$ \\
$\mathrm{~s}$ & $24-28$ & & & & & \\
$\mathrm{sd}$ & $7 / 2 \mathrm{~mm}$ & & & & & \\
\hline
\end{tabular}

Remark. The present material differs from C. tottoni in having a higher number of septa.

Occurrence. Early Aptian (Dufrenoyia furcata Zone), La Serna, El Morrón and Las Mingachas; Late Aptian (Epicheloniceras martini Zone), Cabezo de las Hoyas.

Occurrence elsewhere. Barremian-Early Albian of the western Tethys and the western Atlantic.

Family Thamnasteriidae Reuss, 1864

Genus Holocoenia Milne-Edwards and Haime, 1851

Holocoenia bendukidzeae (Sikharulidze, 1972)

Fig. 10D, H

Material. MGSB 74629B, 74632; 3 thin-sections.

\section{Dimensions}

\begin{tabular}{lllllll}
\hline (74632) & $n$ & $\min -\max$ & $\mu$ & $s$ & $v$ & $\mu \pm s$ \\
\hline $\mathrm{cl}$ & 30 & $0.800-1.456$ & 1.122 & 0.171 & 15.2 & $0.95-1.29$ \\
$\mathrm{ccd}$ & 30 & $1.015-1.903$ & 1.418 & 0.267 & 18.8 & $1.15-1.68$ \\
$\mathrm{~s}$ & $16-20$ & & & & & \\
\hline
\end{tabular}

Remark. Contrary to the recent revision of the genus (Löser, 2009a), a third species is included here the dimensions of which are exactly between those of $H$. jaccardi and $H$. micrantha.

Occurrence. Early Aptian (Dufrenoyia furcata Zone), El Morrón.

Occurrence elsewhere. Hauterivian-Early Aptian of the Tethys.

Genus Mesomorpha Pratz, 1882-1883

Mesomorpha cf. mammillata (Reuss, 1854)

Fig. $10 \mathrm{M}-\mathrm{O}$

Material. MGSB 78446, 78450; 5 thin-sections.

Dimensions

\begin{tabular}{lllllll}
\hline (78450) & $n$ & $\min -\max$ & $\mu$ & $s$ & $v$ & $\mu \pm s$ \\
\hline $\mathrm{cl}$ & 40 & $1.412-1.932$ & 1.716 & 0.139 & 8.1 & $1.57-1.85$ \\
$\mathrm{ccd}$ & 50 & $1.394-2.321$ & 1.748 & 0.243 & 13.9 & $1.50-1.99$ \\
$\mathrm{~s}$ & $16-18$ & & & & & \\
$\mathrm{sk}$ & $5-6$ & & & & & \\
$\mathrm{sd}$ & $8 / 1 \mathrm{~mm}$ & & & & & \\
\hline
\end{tabular}

Remarks. Septal number is lower and the calicular dimensions are smaller than in M. mammillata.
Occurrence. Late Aptian (Epicheloniceras martini Zone), Barranco de la Canal and Villarroya de los Pinares.

Occurrence elsewhere. Hauterivian-Early Albian worldwide.

Suborder Microsolenina Morycowa and Roniewicz, 1995

Family Leptophylliidae Vaughan, 1905

Genus Ovalastrea d'Orbigny, 1849

\section{Ovalastrea sp.}

Fig. 10Q, R

Material. MGSB 78470; 1 thin-section.

Dimensions

\begin{tabular}{lllllll}
\hline (78470) & $n$ & $\min -\max$ & $\mu$ & $s$ & $v$ & $\mu \pm s$ \\
\hline cl min & 12 & $3.218-4.950$ & 4.039 & 0.584 & 14.4 & $3.45-4.62$ \\
cl max & 10 & $4.991-6.505$ & 5.960 & 0.472 & 7.9 & $5.48-6.43$ \\
ccd & 15 & $4.549-6.826$ & 5.658 & 0.757 & 13.3 & $4.90-6.41$ \\
$\mathrm{~s}$ & $55-70$ & & & & & \\
sd & $8 / 2 \mathrm{~mm}$ & & & & & \\
\hline
\end{tabular}

Occurrence. Late Aptian (Epicheloniceras martini Zone), Barranco de las Corralizas.

Occurrences elsewhere. Barremian-Early Aptian of the Tethys and western Atlantic.

Genus Thalamocaeniopsis Alloiteau, 1953

Thalamocaeniopsis ouenzensis Alloiteau, 1953

Fig. $11 \mathrm{~A}-\mathrm{C}$

Material. MGSB 74620, 78439, 78444, 78447, 78451, 78453, 78456 , 78458, 78459, 78463, 78464, 78465, 78466, 78468, 78471, 78473, 78475, 78477, 78483, 78486, 78490, 78491; 30 thin-sections.

Dimensions

\begin{tabular}{lllllll}
\hline (78486) & $n$ & $\min -\max$ & $\mu$ & $s$ & $v$ & $\mu \pm s$ \\
\hline cl min & 10 & $3.528-5.800$ & 4.568 & 0.773 & 16.9 & $3.79-5.34$ \\
cl max & 10 & $5.329-8.271$ & 6.493 & 0.824 & 12.6 & $5.66-7.31$ \\
ccd & 20 & $5.110-7.293$ & 5.966 & 0.644 & 10.8 & $5.32-6.61$ \\
s & $70-80$ & & & & & \\
sd & $14 / 5 \mathrm{~mm}$ & & & & & \\
\hline
\end{tabular}

Occurrence. Early Aptian (Dufrenoyia furcata Zone), Las Mingachas; Late Aptian (Epicheloniceras martini Zone), Cabezo de las Hoyas, Barranco de la Canal, Barranco de las Corralizas and Villarroya de los Pinares.

Occurrence elsewhere. Late Aptian-Early Albian of the central Tethys.

Thalamocaeniopsis sp.

Fig. $11 \mathrm{E}-\mathrm{G}$

Material. MGSB 74621; 1 thin-section. 
Dimensions

\begin{tabular}{lllllll}
\hline (74621) & $n$ & $\min -\max$ & $\mu$ & $s$ & $v$ & $\mu \pm s$ \\
\hline cl min & 5 & $2.658-3.853$ & 3.329 & 0.595 & 17.8 & $2.73-3.92$ \\
cl max & 6 & $3.338-4.738$ & 4.135 & 0.487 & 11.7 & $3.64-4.62$ \\
ccd & 12 & $2.783-5.427$ & 4.344 & 0.885 & 20.3 & $3.45-5.23$ \\
s & $36-40$ & & & & & \\
sd & $8 / 2 \mathrm{~mm}$ & & & & & \\
\hline
\end{tabular}

Occurrence. Early Aptian (Dufrenoyia furcata Zone), Las Mingachas.

Occurrence elsewhere. Aptian-Early Cenomanian of the western Tethys.

Family Microsolenidae Duncan, 1884

Genus Eocomoseris Melnikova et al., 1993

Eocomoseris raueni Melnikova et al., 1993

Fig. 11I-K

Material. MGSB 74611; 3 thin-sections.

Dimensions

\begin{tabular}{lllllll}
\hline (74611) & $n$ & $\min -\max$ & $\mu$ & $s$ & $v$ & $\mu \pm s$ \\
\hline $\mathrm{cl}$ & 10 & $1.974-2.758$ & 2.367 & 0.289 & 12.2 & $2.07-2.65$ \\
$\mathrm{ccd}$ & 10 & $1.957-3.608$ & 2.855 & 0.534 & 18.7 & $2.32-3.39$ \\
$\mathrm{~s}$ & 24 & & & & & \\
$\mathrm{sd}$ & $8 / 2 \mathrm{~mm}$ & & & & & \\
\hline
\end{tabular}

Occurrence. Early Aptian (Dufrenoyia furcata Zone), La Serna.

Occurrence elsewhere. Hauterivian-Early Cenomanian of the western Tethys, the western Atlantic and the European Boreal region.

Genus Polyphylloseris de Fromentel, 1857

Polyphylloseris cf. kobyi (Prever, 1909)

Fig. 11D, H, L

Material. MGSB 74603, 74609, 74616, 74618, 74622, 74623, 74624, 74634, 74639, 78434, 78457, 78460, 78461; 19 thin-sections.

\section{Dimensions}

\begin{tabular}{lllllll}
\hline (74616) & $n$ & $\min -\max$ & $\mu$ & $s$ & $v$ & $\mu \pm s$ \\
\hline ccd & 20 & $4.891-8.182$ & 6.704 & 1.149 & 17.1 & $5.55-7.85$ \\
$\mathrm{c}$ & 10 & $2.963-3.876$ & 3.464 & 0.256 & 7.4 & $3.20-3.72$ \\
$\mathrm{~s}$ & $40-50$ & & & & & \\
sd & $7 / 2 \mathrm{~mm}$ & & & & & \\
sdt & $5 / 1 \mathrm{~mm}$ & & & & & \\
\hline
\end{tabular}

Remark. The holotype of Polyphylloseris kobyi has slightly smaller calicular dimensions (ccd, 5-6 mm) and a higher number of septa (50-60).

Occurrence. Early Aptian (Dufrenoyia furcata Zone), La Serna, El Morrón and Las Mingachas; Late Aptian (Epicheloniceras martini Zone), Barranco de las Corralizas.
Polyphylloseris simondsi (Wells, 1932)

Fig. 10S, T

Material. MGSB 74635; 4 thin-sections.

Dimensions

\begin{tabular}{lllllll}
\hline (74635) & $n$ & $\min -\max$ & $\mu$ & $s$ & $v$ & $\mu \pm s$ \\
\hline ccd & 11 & $4.230-6.639$ & 5.640 & 0.813 & 14.4 & $4.82-6.45$ \\
$\mathrm{~s}$ & $60-70$ & & & & & \\
$\mathrm{sd}$ & $7 / 2 \mathrm{~mm}$ & & & & & \\
\hline
\end{tabular}

Occurrence. Early Aptian (Dufrenoyia furcata Zone), El Morrón.

Occurrence elsewhere. Aptian-Early Albian of the central Tethys and the western Atlantic.

\section{Discussion}

\subsection{Faunal composition}

The coral fauna represents the combination of seven sample locations encompassing two ammonite zones (Figs. 1 and 2). Each sample location contributes with a comparably low amount of species: from Villarroya de los Pinares with only three species to Barranco de las Corralizas with nine species (in Villarroya de los Pinares only three coral colonies were collected, thus the very low species diversity is a sampling artefact). Coeval faunas found in platform carbonates in the Barremian of the Ardèche platform (southern France; Löser and Ferry, 2006), the Late Barremian-Early Aptian of the Helvetic Shelf (France and Switzerland; Scholz, 1984; Baron-Szabo, 1997), the Early Aptian of the Tatra platform (Carpathians; Morycowa and Lefeld, 1966) and the Late Aptian of the southern Maestrat Basin (eastern Iberia; Tomás et al., 2008), yielded similar numbers of species. Coral species diversities ranging between three and nine species are comparatively low when compared with diversities exhibited by many Recent (e.g., Huston, 1985; Harriott et al., 1994; Edinger et al., 2008; Thomson and Frisch, 2010) and ancient (e.g., Fürsich and Wendt, 1977; Kiessling and Flügel, 2002) coral communities.

In the Recent, low coral species diversity has been frequently linked to disturbed communities (e.g., Coles, 2003; Larsen and Webb, 2009) or to latitudes with environmental conditions close to the threshold for coral survival (Perry and Larcombe, 2003). According to Masse et al. (2000), the palaeolatitude of the Galve Sub-basin (western Maestrat Basin) during the Aptian was around $25-26^{\circ} \mathrm{N}$. This palaeolatitude was similar to that of the southern Maestrat Basin and lower than those of the Ardèche platform, Tatra platform, and the Helvetic Shelf (Masse et al., 2000). Nowadays, coral populations thriving in similar latitudes are considered highlatitude communities (e.g., Riegl, 2003). However, the Aptian oceanographic circulation patterns and climatic belts were probably very different from those of today (Skelton, 2003). Furthermore, studies dealing with latitudinal distribution of coral species diversity do not exist for the Aptian. Therefore, it cannot be proven that a latitudinal effect is responsible for the relatively low coral species diversity recorded in the Galve Sub-basin.

Drastic changes of biota or lithofacies indicating harsh or changing environmental conditions have not been identified on the time-equivalent platform tops, where the lithofacies and biotic components are relatively uniform and dominated by typical and widespread Aptian platform dwellers such as rudist bivalves, 
Chondrodonta, oysters, nerineid gastropods, corals, dasycladaceans, miliolids, and orbitolinids (Bover-Arnal et al., 2009, 2010, 2011a). Factors limiting the species diversity of a coral community can be numerous and very variable including geographic isolation, competition with other species, substrate, nutrient availability, turbidity, sedimentation rate, temperature, aragonite saturation, salinity, water depth and water energy. It is not possible to interpret the effect of each of these variables on a coral population from the geological record. Therefore, a simple explanation for the observed comparably low coral species diversity cannot be provided.

The coral fauna encompasses almost exclusively very common genera and species; uncommon are only the genera Agrostyliastraea and Procladocora. Agrostyliastraea was up to now known only from the Early Cretaceous of Greece (Morycowa and MarcopoulouDiacantoni, 2002) and the present material (Fig. 9A, B) surely represents a new species. Procladocora (Fig. 9I-K) was hitherto almost unknown in Early Cretaceous deposits, except for one indication in the Barremian of France (Löser, 2010a).

The taxonomic profile identified in the study area includes only four suborders (out of the ten present during the Aptian; e.g., Löser, 2009b). The absence of the suborder Stylinina, which is commonly present on Barremian-Early Albian carbonate platforms of the Tethys realm, is especially remarkable. In addition, comparing the distribution of species among the various sample areas and stratigraphic intervals, no clear separation between the late Early and early Late Aptian populations can be found. This may be owing to the relatively long ranges of the coral species (Fig. 12) and/or because of relatively stable environmental conditions during the time intervals concerned.

\subsection{Stratigraphical distribution}

Sixteen out of the 21 species sampled have been reported from localities outside of the study area (Fig. 12). The distribution of most species is concentrated in the Late Barremian-Early Albian timespan. This distribution coincides with the general availability of Early Cretaceous coral faunas (e.g., Löser and Ferry, 2006). The total number of faunas decreased continuously during the late Early Aptian and then dramatically dropped during the Early Albian (Löser, 2009b). Knowledge of the taxonomic composition of coral faunas of the Late Aptian is therefore limited.

\subsection{Palaeobiogeographical distribution}

The coral communities of the Galve Sub-basin show relationships with geographically closely located faunas of Barremian-Early Albian age. Sixteen species are shared with faunas from the western and central Tethys, ten with faunas in the western Atlantic and Caribbean, and nine with faunas from the eastern Tethys or the western Pacific. Eastern Tethyan faunas (e.g., Tibet) are stratigraphically poorly constrained but differ taxonomically (Liao and Xia, 1994; Löser and Liao, 2001) from the fauna reported here. Western Pacific faunas (e.g., Japan) are found mainly

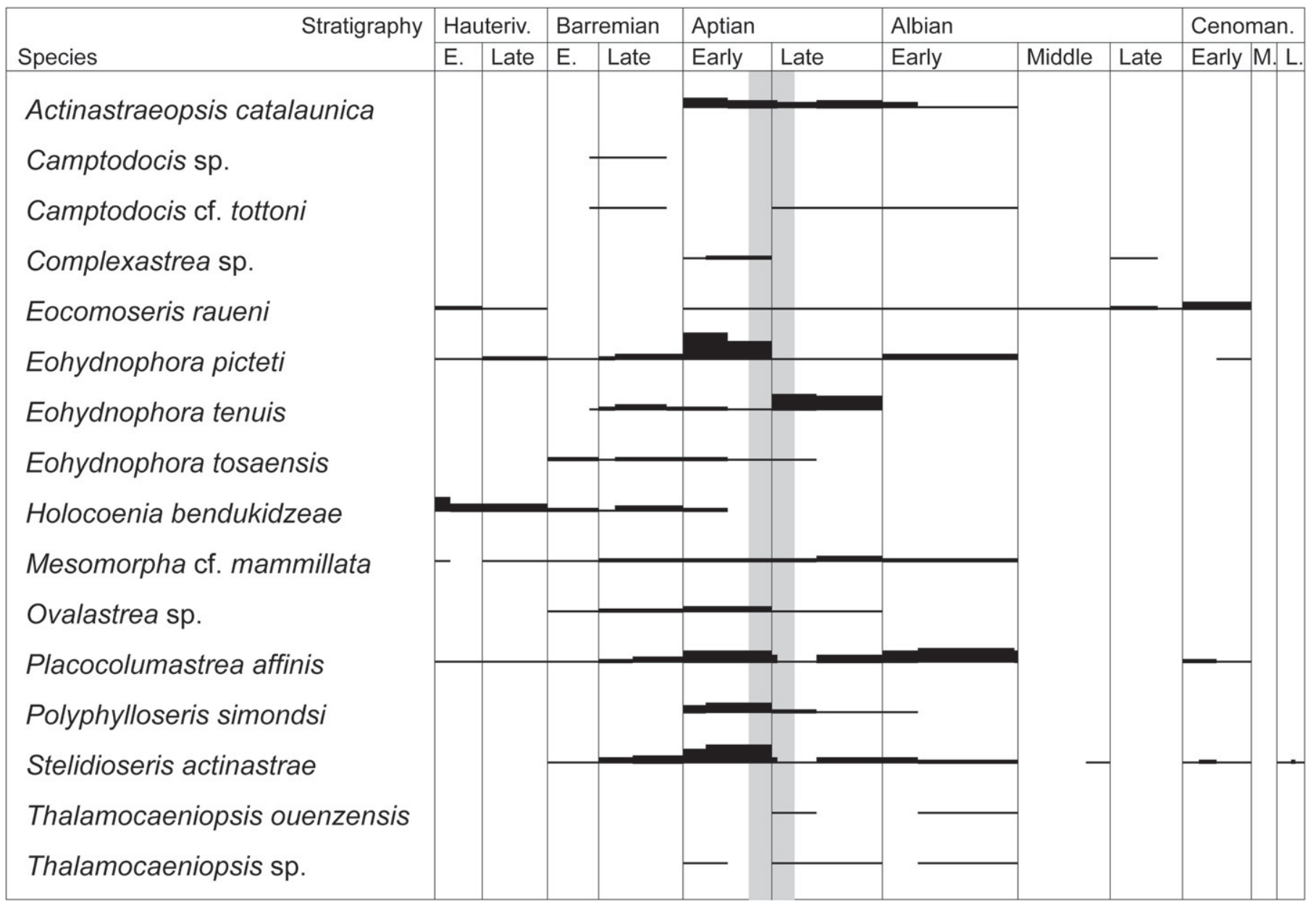

Fig. 12. Stratigraphic distribution and abundances of species of the fauna studied. The thickness of the black bars indicates the abundance at other localities in which the species concerned was found. Grey bar indicates the time interval recorded in the study area. 
in siliciclastic deposits and are taxonomically different in their composition (Löser, 2002).

\subsection{Coral palaeoecology}

Physiologic and environmental factors controlling hermatypic coral growth mainly include the efficiency of the photosymbionts, the metabolism of the coral polyps, sedimentation rate, temperature, salinity, water energy, light intensity, aragonite saturation state, and concentration of nutrients (e.g., Rogers, 1990; Kleypas et al., 1999a,b, 2001; Manzello and Lirman, 2003; Guinotte et al., 2003; Stanley, 2003, 2006; Hallock, 2005; Sanders and BaronSzabo, 2005; Lough and Cooper, 2011). Considering this multitude of interacting parameters, care must be taken when interpreting the palaeoecology of a coral community. Nevertheless, some ecological features and parameters can be discussed based on the observed geologic record.

\subsubsection{Growth fabric, growth rates and substrate}

The Aptian colonial scleractinian corals of the western Maestrat Basin were not reef-builders, neither in slope environments on which this study is based nor in platform settings (Bover-Arnal et al., 2009, 2010). The corals analysed here were level-bottom communities, which flourished on marly and platform-derived skeletal lime-mud substrates. These colonies exhibit an unbound growth fabric with a low to medium degree of development (Figs. 4D, E, 6A-D, 7A) or are fused into only small, metre-sized bioherms (Figs. 3E and 6E). The loose growth fabric developed on soft substrates. This is a widespread trait of Early Cretaceous and other Mesozoic coral-bearing sedimentary successions (e.g., Gili, 1993; Baron-Szabo, 1997, 2003; Sanders and Pons, 2001; Rosen et al., 2002; Sanders and Baron-Szabo, 2005; Löser and Ferry, 2006; Löser and Saldaña Villodre, 2008; Tomás et al., 2008). To some extent, comparable fabrics are also seen in present-day marginal and non-reef-building environments, where corals settle only sparsely on soft or hard substrates, or generate carpets or small banks (e.g., Riegl and Piller, 1999; Benzoni et al., 2003; Perry and Larcombe, 2003). Such coral ecosystems with limited framework development are mainly found in high-latitude, turbid or upwelling-influenced settings (Kleypas et al., 1999b; Perry and Larcombe, 2003 and references therein).

The community structure exhibited by the Aptian corals studied is relatively uniform and simple (Figs. 6 and 7A) and does not lead to any zonation reflecting water depth or energy. Furthermore, there are no substantial differences between the species compositions and community structures exhibited by the Early and Late Aptian populations. Thus, the environmental conditions were presumably similar along the slope profile and throughout the stratigraphic intervals studied.

The corals show a predominance of decimetre-sized flattened and domal colonies (Figs. 3D, E, 4D, E, 5C, D, 6, 7E, 8). This is common in Cretaceous communities but implies limited growth rates or early death if compared with present-day hermatypic colonies, which can easily reach metre sizes in low-latitude regions (e.g., Lough and Cooper, 2011). Restricted growth rates are also frequently reported from modern marginal and non-reef-building coral environments (e.g., Harriott, 1999; Moyer et al., 2003). Unfortunately, growth bands have not been recognized in the Aptian specimens analysed, hence a direct estimation of growth rates is not possible.

The corals settled on slopes in calm environments, probably below the storm wave-base, as indicated by the absence of coral rubble or dislodged or damaged colonies. The presence of marls and micrite in the coral-bearing sedimentary deposits also implies quiet conditions. The widespread occurrence of coral colonies throughout the marly and marly limestone intervals indicates that recruitment occurred uninterruptedly at a geological scale. Shedding episodes of platform-derived sediment periodically interrupted these quiet habitats. Shifting sediments do not favour the establishment of coral larvae (e.g., Rogers, 1990), but once quiet conditions ruled again, the skeletal components provided a hard substratum for larval attachment. Moreover, coral larvae also established themselves on partially buried dead scleractinians (Figs. 3E, 6E, F, 7C).

Soft substrates are a limiting factor for some modern coral species (Benzoni et al., 2003). However, the Aptian faunas found on the marly slopes apparently had optimal ecological conditions for their development, given that many of the slope deposits recognized in the study area contain colonies in life position. The occurrence of few metre-sized colonies, which are exceptionally large for the Cretaceous Period (e.g., Götz et al., 2005; Löser and Ferry, 2006; Tomás et al., 2008), also indicates that these marly slopes provided a favourable ecological environment for coral growth. Besides the scattered presence of small clusters of closely packed Polyconites hadriani (Bover-Arnal et al., 2009, 2011a; Skelton et al., 2010), the absence of abundant congregations of other large calcifying benthic organisms suggests that the corals did not find much ecological competition. Coral growth around bioerosional structures, which is indicative of an ante-mortem process, has been identified in only four colonies. Therefore, in this respect, competition with bioeroders was probably little given that nearly all of the boring traces observed were produced after the death of the colony. However, it is reasonable to think that competition for the hard substrates provided by dead scleractianians would have existed between corals, bioeroders and non-calcifying organisms.

With the exception of periodic shedding of platform-top material, sedimentation rates were at levels that permitted the settlement and growth of the corals. The presence of heavily bioeroded colonies (Fig. 8) indicates that these were exposed long enough to be colonized by endolithic organisms. Nevertheless, episodic burial of living specimens should not be ruled out given the occurrence of colonies devoid of bioerosional structures (e.g., Fig. 7C-F). The partially constratal growth fabric of a few large colonies (e.g., Fig. 7B) is more likely to be the consequence of sinking of the colony into the unconsolidated substrate than of sedimentation stress.

\subsubsection{Relative sea-level changes}

The corals flourished during high-frequency (Milankovitchscale?) transgressive pulses of relative sea-level (Bover-Arnal et al., 2009). During phases of rising relative sea-level, shedding of carbonate from the platform top was halted or reduced, leaving starved marly slopes, which were colonized by the scleractinians. Falls of relative sea level increased the hydraulic energy on the platform, generating shedding episodes by which the marly environments rich in autochthonous colonies were buried (Figs. $3 \mathrm{~A}-\mathrm{C}$, $4 \mathrm{~A}, \mathrm{~B}, 5 \mathrm{~A}, \mathrm{~B})$. Storm events, earthquakes or oversteepening of the platform margin could also account for such episodes of basinward transport of coarse platform-derived material (Bover-Arnal et al., 2009). A new generation of scleractinians then settled on the substrate furnished by these floatstone and rudstone deposits, giving rise to relatively continuous coral-rich levels (Figs. 3A-C, 4A, $\mathrm{B}, 5 \mathrm{~A}, \mathrm{~B})$. The colonies buried by platform material commonly lack bioerosional structures, indicating that they were rapidly covered. In contrast, the colonies exhibiting abundant bioerosional structures are covered by marls, suggesting a slower burial.

\subsubsection{Terrigenous sediment and nutrients}

The exact distance between the shoreline and the slopes where these corals developed is difficult to determine owing to 
present-day erosion and to the Albian, Late Cretaceous and Neogene cover. However, the absence of coarse siliciclastic sands implies that the colonies were not affected by direct terrigenous runoff and presumably flourished outside of the coastal turbid zone. Fine-grained siliciclastic sediment was brought by suspension to the slope environments and mixed with lime mud derived from the platform top to form the marls. Part of the lime mud could have also an in situ origin (e.g., Keim and Schlager, 1999).

Elevated concentrations of nutrients could have been periodically carried into the slope settings along with the fine-grained terrigenous sediments, or they were brought by upwelling currents. However, effects of high nutrient inputs on the coral populations cannot be detected. A common sign of nutrient enrichment in modern coral ecosystems is a shift to an alternative stable state dominated by macroalgae (Koop et al., 2001; McCook et al., 2001; Thacker et al., 2001), with high abundance of clionid sponges (Holmes, 2000; Rützler, 2002). However, traces of boring sponges are virtually non-existent in the corals investigated. Macroalgae are mostly fleshy and thus are not preserved in the geological record. Red-algal or microbial crusts overlying the coral surfaces are absent in the colonies surveyed, and changes in the structure and composition of the calcifying benthic communities dwelling in the corresponding platform-top settings that could be indicative of eutrophication have not been reported (Bover-Arnal et al., 2009, 2010, 2011a). The stratigraphic intervals containing strongly bioeroded colonies could indeed reflect phase shifts as a result of eutrophication in which the coral ecosystems became dominated by endolithic organisms (e.g., Hallock and Schlager, 1986). However, long-exposed dead coral surfaces would also result in high rates of bioerosion.

\subsection{Symbionts, ocean acidification and bleaching}

Whether the Aptian faunas studied here were symbiont bearing (zooxanthellate) like modern hermatypic corals or non-symbiont bearing (azooxanthellate) such as present-day ahermatypic corals, is unknown. However, they settled along slopes, which never surpassed bathymetries deeper than $30 \mathrm{~m}$ below the platform top (Figs. 3A-C, 4A-D, 5A, B). Therefore, they developed in all likelihood within the photic zone (modern hermatypic corals can thrive at depths of $>70$ m; e.g., Goreau and Wells, 1967; Liddell and Ohlhorst, 1988; Achituv and Dubinsky, 1990). In addition, the presence of different levels of corallite integration (Figs. 9-11), distinct colony shapes such as branching, domal, irregular massive, columnar and platy (e.g., Figs. 3D,E, 4E, 5C, D, 7B, C, E, F), as well as the existence of few colonies attaining dimensions in metres (Fig. 7B, C), point to z-like assemblages (sensu Rosen, 2000); ergo forms resembling present-day zooxanthellate corals (Wood, 1999; Stanley, 2003).

In this respect, Stanley and Helmle (2010) reported the presence of growth bands in large and massive Middle Triassic colonial corals that suggest light-induced responses and, thus, the probable existence of zooxanthellate species already in the early Mesozoic. The results of stable isotope analyses performed on Late Triassic coral skeletons by Stanley and Swart (1995) and on the organic matrix from specimens of the same age by Muscatine et al. (2005) also support this hypothesis.

Although possibly photosymbiotic, the fact that the studied scleractinians were not reef-building coral communities is not surprising (Rosen, 2000; Pomar and Hallock, 2008). Large and extensive coral frameworks resembling modern low-latitude coral reefs are rare in the geological record (Wood, 1998). Their presence is commonly associated with relatively low atmospheric $\mathrm{CO}_{2}$ concentrations during long-term cooling trends or interglacial climates, such as during the Late Paleogene-Recent time interval
(Kleypas et al., 2001) and probably also during the Late Triassic Epoch (Kiessling, 2010). Hence, high atmospheric $\mathrm{CO}_{2}$ levels, which have been prevalent throughout much of Earth's history (Berner and Kothavala, 2001), seem to be unfavourable for coral-reef growth (Kleypas et al., 1999a, 2001; Hallock, 2005; Kiessling, 2010; Zagmani et al., 2012). In this regard, the deleterious effects of rising atmospheric $\mathrm{CO}_{2}$ concentrations on the reef-building capacity of corals by sea-water acidification and ensuing declining calcification can be seen in present-day oceans (e.g., Hoegh-Guldberg et al., 2007; De'ath et al., 2009; Fabricius et al., 2011). Furthermore, the strong connection between coral bleaching and thermal stress (e.g., Berkelmans and Oliver, 1999; HoeghGuldberg, 1999; Hughes et al., 2003) suggests that rising sea-water temperature as a result of increased $\mathrm{pCO}_{2}$ would also cause reef carbonate production to decline by weakening the corals (Kleypas et al., 2001). Several studies indicate that, if the current trend of global warming persists, the low-latitude coral frameworks may be progressively replaced by level-bottom communities or small bioherms resembling the community structures found in the Cretaceous fossil record, or those developed in modern marginal and non-reef-building coral environments (e.g., Kleypas et al., 2001; Guinotte et al., 2003; Hoegh-Guldberg et al., 2007).

The Early Aptian corals studied were not coeval with the climatic and oceanographic changes leading to Oceanic Anoxic Event 1a (OAE1a) (Bover-Arnal et al., 2011b). They are found within the Dufrenoyia furcata Biozone, whereas the OAE1a is older, located in the upper part of the Deshayesites forbesi Biozone (MorenoBedmar et al., 2010, 2012; Reboulet et al., 2011). Whether or not the Early and Late Aptian coral populations investigated cooccurred with perturbations related to other OAEs is unknown.

An interdependent hypothesis on why Cretaceous corals did not build structures such as modern tropical reef frameworks concerns the efficiency of the photosymbionts (Stanley, 2006). Zooxanthellae increase coral growth rates through accelerated calcification and are responsible for the present-day rapid reef growth. Phylogenetic analyses of the dinoflagellate genus Symbiodinium have characterized eight divergent clades with symbionts adapted to different temperatures and irradiances (LaJeunesse, 2005 and references therein). Some modern species of hermatypic corals are able to adapt to changing environmental conditions by modifying their symbiont communities (Baker et al., 2004; Rowan, 2004). If Mesozoic corals hosted dinoflagellate algal symbionts that were not as diversified and specialized as those of today, this could also account for the scarcity of vast coral reef systems during this era (Stanley, 2006).

\section{Conclusions}

Comparatively low coral species diversities and the absence of reef frameworks do not necessarily imply unfavourable environmental conditions for coral growth. The present case study of Aptian non-reef coral assemblages with relatively low species diversity demonstrates that the marly slopes of the western Maestrat Basin offered optimal ecological conditions for their development: some of the colonies exhibit extraordinarily large sizes (up to $2.3 \mathrm{~m}$ width) in comparison to other Cretaceous occurrences, and they are persistent and resilient throughout the studied time interval.

Given our popular but biased view of coral community structure based on the idyllic picture of recent tropical reefs, this paper emphasizes that not all fossil coral-bearing sedimentary systems were reefs and highlights the predominance throughout the Cretaceous of such non-reef coral populations. Today's coral reefs are exceptional. In contrast, over geological timescales, unbound coral growth fabrics such as those reported herein are perhaps a norm in coral community structure. 


\section{Acknowledgements}

Sara Tomás and Marc Aurell are acknowledged for their constructive comments. Sara Tomás is also thanked for providing a bibliography on Early Cretaceous corals. Special thanks are due to David Jaramillo-Vogel for fruitful discussions. We are grateful to Lucinda Puebla who assisted in measuring the examined samples and in compiling the fossil plates. Funding was provided by the Swiss National Science Foundation grants no. 20-121545 and 20-137568, the I+D+i research project: CGL2008-04916, the Consolider-Ingenio 2010 programme, under CSD 2006-0004 “TopoIberia" and the Grup Consolidat de Recerca "Geologia Sedimentària" (2009SGR-1451).

\section{References}

Achituv, Y., Dubinsky, Z. 1990. Evolution and zoogeography of coral reefs. In: Dubinsky, Z (Ed.), Coral Reefs: Ecosystems of the World. Elsevier, Amsterdam, pp. 1-9.

Aillud, G.S., 2001. Palaeocology and Sequence Stratigraphy: Lower Cretaceous, Lusitanian Basin, Portugal. Unpublished PhD thesis, University of Plymouth, Plymouth, $341 \mathrm{pp}$.

Baker, A.C., Starger, C.J., McClanahan, T.R., Glynn, P.W., 2004. Corals's adaptive response to climate change. Nature 430,741 .

Baron-Szabo, R.C., 1997. Die Korallenfazies der ostalpinen Kreide (Helvetikum Allgäuer Schrattenkalk; Nördliche Kalkalpen: Brandenberger Gosau). Taxonomie, Palökologie. Zitteliana 21, 3-97.

Baron-Szabo, R.C., 2003. Taxonomie und Ontogenie von Korallen der ostalpinen Oberkreide (Hochmoos- und Grabenbach-schichten, Gosau Gruppe, Santon). Jahrbuch der Geologischen Bundesanstalt 143, 107-201.

Benzoni, F., Bianchi, C.N., Morri, C., 2003. Coral communities of the northwestern Gulf of Aden (Yemen): variation in framework building related to environmental factors and biotic conditions. Coral Reefs 22, 475-484.

Berkelmans, R., Oliver, J.K., 1999. Large-scale bleaching of corals on the Great Barrie Reef. Coral Reefs $18,55-60$.

Berner, R.A., Kothavala, Z., 2001. GEOCARB III: a revised model of atmospheric $\mathrm{CO}_{2}$ over Phanerozoic time. American Journal of Science 301, 182-204.

Bover-Arnal, T., Moreno-Bedmar, J.A., Salas, R., Skelton, P.W., Bitzer, K., Gili, E., 2010. Sedimentary evolution of an Aptian syn-rift carbonate system (Maestrat Basin, E Spain): effects of accommodation and environmental change. Geologica Acta 8, 249-280.

Bover-Arnal, T. Salas, R., Skelton, P.W., Gili, E., Moreno-Bedmar, J.A., 2011a. The Aptian carbonate platforms of the western Maestrat Basin: a textbook example of four systems tract-based sequence stratigraphy. In: Arenas, C., Pomar, L. Colombo, F. (Eds.), Pre-Meeting Field trips Guidebook, 28th IAS Meeting, Zaragoza. Sociedad Geológica de España, Geo-Guías 7, pp. 27-64.

Bover-Arnal, T., Salas, R., Martín-Closas, C., Schlagintweit, F., Moreno-Bedmar, J.A., 2011b. Expression of an oceanic anoxic event in a neritic setting: Lower Aptian coral rubble deposits from the western Maestrat Basin (Iberian Chain, Spain). Palaios 26, 18-32.

Bover-Arnal, T., Salas, R., Moreno-Bedmar, J.A., Bitzer, K., 2009. Sequence stratigraphy and architecture of a late Early-Middle Aptian carbonate platform succession from the western Maestrat Basin (Iberian Chain, Spain). Sedimentary Geology 219, 280-301.

Canérot, J., 1974. Recherches géologiques aux confins des chaînes Ibérique et Catalane (Espagne). PhD thesis, ENADIMSA, Toulouse, $517 \mathrm{pp}$.

Canérot, J., Crespo, A., Navarro, D., 1979. Montalbán, hoja n 518 Mapa Geológico de España 1:50.000. $2^{\text {a }}$ Serie. $1^{\text {a }}$ Edición. Servicio de Publicaciones Ministerio de Industria y Energía, Madrid, $31 \mathrm{pp}$.

Canérot, J., Cugny, P., Pardo, G., Salas, R., Villena, J., 1982. Ibérica Central-Maestrazgo. In: García, A. (Ed.), El Cretácico de España. Universidad Complutense de Madrid, pp. 273-344.

Castro, J.M., De Gea, G.A., Ruiz-Ortiz, P.A., Nieto, L.M., 2008. Development of carbonate platforms on an extensional (rifted) margin: the Valanginian-Albian record of the Prebetic of Alicante (SE Spain). Cretaceous Research 28, 848-860.

Clack, NJ. 2001. Palaeoecological reconstruction of Lower Cretaceous (Barremian-Aptian) coral communities of southern France. Bulletin of Tohoku University Museum 1, 96-113.

Coles, S.L., 2003. Coral species diversity and environmental factors in the Arabian Gulf and the Gulf of Oman: a comparison to the Indo-Pacific region. Atoll Research Bulletin 507, 1-19.

De'ath, G., Lough, J.M., Fabricius, K.E., 2009. Declining coral calcification on the Great Barrier Reef. Science 323, 116-119.

Dupraz, C., Strasser, A., 1999. Microbialites and micro-encrusters in shallow coral bioherms (Middle to Late Oxfordian, Swiss Jura Mountains). Facies 40, 101-130.

Dupraz, C., Strasser, A., 2002. Nutritional modes in coral-microbialite reefs (Jurassic, Oxfordian, Switzerland): evolution of trophic structure as a response to environmental change. Palaios 17, 449-471.

Edinger, E.N., Kolasa, J., Risk, M.J., 2008. Biogeographic variation in coral species diversity on coral reefs in three regions of Indonesia. Diversity and Distributions 6, 113-127.
Embry, J-C. Vennin, E. Van Buchem, F.S.P., Schroeder, R., Pierre, C., Aurell, M., 2010 Sequence stratigraphy and carbon isotope stratigraphy of an Aptian mixed carbonate-siliciclastic platform to basin transition (Galve Sub-basin, NE Spain). In: Van Buchem, F.S.P., Gerdes, K., Esteban, M. (Eds.), Mesozoic and Cenozoic Carbonate Systems of the Mediterranean and the Middle East, Stratigraphic and Diagenetic Reference Models. Geological Society, London, Special Publication, vol. 329, pp. 113-143

Fabricius, K.E., Langdon, C., Uthicke, S., Humphrey, C., Noonan, S., De'ath, G. Okazaki, R. Muehllehner, N. Glas, M.S., Lough, J.M. 2011. Losers and winners in coral reefs acclimatized to elevated carbon dioxide concentrations. Nature Climate Change 1, 165-169.

Fürsich, F.T., Wendt, J., 1977. Biostratinomy and palaeoecology of the Cassian Formation (Triassic) of the southern Alps. Palaeogeography, Palaeoclimatology, Palaeoecology 22, 257-323.

Gautier, F., 1980. Villarluengo, hoja n 543 Mapa Geológico de España 1:50.000. $2^{\mathrm{a}}$ Serie. $1^{\text {a }}$ Edición. Servicio de Publicaciones, Ministerio de Industria y Energía, Madrid, 45 pp.

Gili, E., 1993. Facies and geometry of Les Collades de Basturs carbonate platform, Upper Cretaceous, south-central Pyrenees. In: Simo, J.A.T., Scott, R.W., Masse, J.-P. (Eds.), Cretaceous Carbonate Platforms. American Association of Petroleum Geologists, Memoir 56, pp. 343-352.

Gili, E., Masse, J.-P., Skelton, P.W., 1995. Rudists as gregarious sediment-dwellers, not reef-builders, on Cretaceous carbonate platforms. Palaeogeography, Palaeoclimatology, Palaeoecology 118, 245-267.

Goreau, T.F., Wells, J.W., 1967. The shallow-water Scleractinia of Jamaica: revised list of species and their vertical distribution range. Bulletin of Marine Science 17 $442-453$

Götz, S., Löser, H., Schmid, D.U., 2005. Reef development on a deepening platform: two Early Cretaceous coralgal patch reefs (Catí, Llàcova Formation, eastern Spain) compared. Cretaceous Research 26, 864-881.

Guinotte, J.M., Buddemeier, R.W., Kleypas, J.A., 2003. Future coral reef habitat marginality: temporal and spatial effects of climate change in the Pacific basin. Coral Reefs 22, 551-558.

Hallock, P., 2005. Global change and modern coral reefs: new opportunities to understand shallow-water carbonate depositional processes. Sedimentary Geology 175, 19-33.

Hallock, P., Schlager, W., 1986. Nutrient excess and the demise of coral reefs and carbonate platforms. Palaios 1, 389-398.

Harriott, V.J., 1999. Coral growth in subtropical eastern Australia. Coral Reefs 18, 281-291.

Harriott, V.J., Smith, S.D.A., Harrison, P.L., 1994. Patterns of coral community structure of subtropical reefs in the Solitary Islands Marine Reserve, Eastern Australia. Marine Ecology Progress Series 109, 67-76.

Helm, C., Schülke, I., 1998. A coral-microbialite patch-reef from the Late Jurassic (florigemma-Bank, Oxfordian) of NW Germany (Süntel Mountains). Facies 39, 75-104.

Helm, C., Schülke, I., 2006. Patch reef development in the florigemma-Bank member (Oxfordian) from the Deister Mts. (NW Germany): a type example for Late Jurassic coral thrombolite thickets. Facies 52, 441-467.

Hoegh-Guldberg, O., 1999. Climate change, coral bleaching and the future of the world's coral reefs. Marine Freshwater Research 50, 839-866.

Hoegh-Guldberg, O., Mumby, P.J., Hooten, A.J., Steneck, R.S., Greenfield, P. Gomez, E., Harvell, C.D., Sale, P.F., Edwards, A.J., Caldeira, K., Knowlton, N., Eakin, C.M., Iglesias-Prieto, R., Muthiga, N., Bradbury, R.H., Dubi, A. Hatziolos, M.E., 2007. Coral reefs under rapid climate change and ocean acidification. Science 318, 1737-1742.

Holmes, KE, 2000. Effects of eutrophication on bioeroding sponge communities with the description of new West Indian sponges, Cliona spp. (Porifera: Hadromerida: Clionidae). Invertebrate Biology 119, 125-138.

Hughes, T.P., Baird, A.H., Bellwood, D.R., Card, M., Connolly, S.R., Folke, C., Grosberg, R. Hoegh-Guldberg, O., Jackson, J.B.C., Kleypas, J., Lough, J.M., Marshall, P. Nyström, M., Palumbi, S.R., Pandolfi, J.M., Rosen, B., Roughgarden, J., 2003. Climate change, human impacts, and the resilience of coral reefs. Science 301, 929-933.

Huston, M.A., 1985. Patterns of species diversity on coral reefs. Annual Review of Ecology and Systematics 16, 140-177.

Insalaco, E., 1996. Upper Jurassic microsolenid biostromes of northern and central Europe: facies and depositional environment. Palaeogeography, Palaeoclimatology, Palaeoecology 121, 169-194.

Insalaco, E., 1998. The descriptive nomenclature and classification of growth fabrics in fossil scleractinian reefs. Sedimentary Geology 118, 159-186.

Insalaco, E., Hallam, A., Rosen, B., 1997. Oxfordian (Upper Jurassic) coral reefs in Western Europe: reef types and conceptual depositional model. Sedimentology $44,707-734$

Keim, L., Schlager, W., 1999. Automicrite facies on steep slopes (Triassic, Dolomites, Italy). Facies $41,15-26$.

Kennedy, D.M., Woodroffe, C.D., 2002. Fringing reef growth and morphology: a review. Earth-Science Reviews 57, 255-277.

Kiessling, W., 2010. Reef expansion during the Triassic: spread of photosymbiosis balancing climatic cooling. Palaeogeography, Palaeoclimatology, Palaeoecology 290, 11-19.

Kiessling W, Flügel, E, 2002. Paleoreefs - a database on Phanerozoic reefs. In: Kiessling, W., Flügel, E., Golonka, J. (Eds.), Phanerozoic Reef Patterns. SEPM Special Publication, 72, pp. 77-92.

Klein, R., Mokady, O., Loya, Y., 1991. Bioerosion in ancient and contemporary corals of the genus Porites: patterns and palaeoenvironmental implications. Marine Ecology Progress Series 77, 245-251. 
Kleypas, J.A., Buddemeier, R.W., Archer, D., Gatusso, J.-P., Langdon, C., Opdyke, B.N., 1999a. Geochemical consequences of increased atmospheric carbon dioxide on coral reefs. Science 284, 118-120.

Kleypas, J.A., Buddemeier, R.W., Gatusso, J.-P., 2001. The future of coral reefs in an age of global change. International Journal of Earth Sciences 90, 426-437.

Kleypas, J.A., McManus, J.W., Meñez, L.A.B., 1999b. Environmental limits to coral development: where do we draw the line? American Zoologist 39, 146-159.

Koop, K., Booth, D., Broadbent, A., Brodie, J., Bucher, D., Capone, D., Coll, J., Dennison, W., Erdmann, M., Harrison, P., Hoegh-Guldberg, O., Hutchings, P. Jones, G.B., Larkum, A.W.D., O'Neill, J., Steven, A., Tentori, E., Ward, S., Williamson, J., Yellowlees, D., 2001. ENCORE: the effect of nutrient enrichment on coral reefs. Synthesis of results and conclusions. Marine Pollution Bulletin 42, 91-120.

LaJeunesse, T.C. 2005. "Species" radiations of symbiotic dinoflagellates in the Atlantic and Indo-Pacific since the Miocene-Pliocene transition. Molecular Biology and Evolution 22, 570-581.

Larsen, M.C., Webb, R.M.T., 2009. Potential effects of runoff, fluvial sediment, and nutrient discharges on the coral reefs of Puerto Rico. Journal of Coastal Research 25, 189-208.

Lathuilière, B., 2000a. Coraux constructeurs du Bajocien inférieur de France. Geobios $33,51-72$

Lathuilière, B., 2000b. Coraux constructeurs du Bajocien inférieur de France. Geobios 33, 153-181

Lathuilière, B., Gaillard, C., Habrant, N., Bodeur, Y., Boullier, A., Enay, R., Hanzo, M., Marchand, D., Thierry, J., Werner, W., 2005. Coral zonation of an Oxfordian reef tract in the northern French Jura. Facies 50, 545-559.

Leinfelder, R.R., 1993. Upper Jurassic reef types and controlling factors. Profil 5, $1-45$.

Liao, W., Xia, J., 1994. Mesozoic and Cenozoic scleractinian corals from Tibet. Palaeontologia Sinica (Zhongguo-gushengwu-zhi) 184, 1-252.

Liddell, W.D., Ohlhorst, S.L., 1988. Hard substrata community patterns, 1-120 m, north Jamaica. Palaios 3, 413-423.

López Llorens, J., 2007. Hallazgo de Imerites giraudi, ammonítido barremiense, en las "Arcillas de Morella". Consecuencias. Batalleria 13, 53-56.

Löser, H., 1994. The Mesozoic corals. Bibliography 1758-1993. Coral Research Bulletin 1, 1-99.

Löser, H., 1998. Cretaceous corals - state of knowledge and current research (for 1996). Zentralblatt für Geologie und Paläontologie 1 (11/12), 1475-1485.

Löser, H., 2002. The Mesozoic corals of the Tohoku University Museum (Sendai, Japan) - an overview. Coral Research Bulletin 7, 109-114.

Löser, H., 2005. Stratigraphy of Cretaceous coral genera. Neues Jahrbuch für Geologie und Paläontologie, Abhandlungen 238, 231-277.

Löser, H., 2009a. Morphology, taxonomy and distribution of the Early Cretaceous coral genus Holocoenia (Scleractinia) and its first record in the Caribbean. Revista Mexicana de Ciencias Geológicas 26, 93-103.

Löser, H., 2009b. Fossile Korallen aus Jura und Kreide. Aufbau, Klassifikation, Bestimmung und Fundmöglichkeiten. CPress Verlag, Dresden, 206 pp.

Löser, H., 2010a. The Barremian coral fauna of the Serre de Bleyton mountain range (Drôme, France). Annalen des Naturhistorischen Museums in Wien 112, 575-612.

Löser, H., 2010b. Revision of the Early Cretaceous coral genus Felixigyra and general remarks on the faviid hydnophoroid coral genera. Rivista Italiana di Paleontologia e Stratigrafia 116, 177-188.

Löser, H., Ferry, S., 2006. Coraux du Barrémien du Sud de la France (Ardèche et Drôme). Geobios 39, 469-489.

Löser, H., Liao, W., 2001. Cretaceous corals from Tibet (China) - biostratigraphical and palaeobiogeographical aspects. Journal of Asian Earth Sciences 19, 661-667.

Löser, H., Saldaña Villodre, J.C., 2008. Colonial corals from the Early Aptian siliciclastic Montlivaltia Marls of Jumilla (Murcia, Spain). Revista Española de Paleontología 23, 1-6.

Lough, J.M., Cooper, T.F., 2011. New insights from coral growth band studies in an era of rapid environmental change. Earth-Science Reviews 108, 170-184.

Manzello, D., Lirman, D., 2003. The photosynthetic resilience of Porties furcata to salinity disturbance. Coral Reefs 22, 537-540.

Masse, J.-P., Bouaziz, S., Amon, E.O., et al., 2000. Early Aptian. In: Dercourt, J., Gaetani, M., Vrielynck, B., et al. (Eds.), Atlas PeriTethys, Palaeogeographical Maps. CCGM/CGMW, Paris. Map 13.

McCook, L.J., Jompa, J., Diaz-Pulido, G., 2001. Competition between corals and algae on coral reefs: a review of evidence and mechanisms. Coral Reefs 19, 400-417.

Montaggioni, L.F., 2005. History of Indo-Pacific coral reef systems since the last glaciation: development patterns and controlling factors. Earth-Science Reviews 71, 1-75.

Moreno-Bedmar, J.A., Company, M., Bover-Arnal, T., Salas, R., Delanoy, G., Martínez, R., Grauges, A., 2009. Biostratigraphic characterization by means of ammonoids of the lower Aptian Oceanic Anoxic Event (OAE1a) in the eastern Iberian Chain (Maestrat Basin, eastern Spain). Cretaceous Research 30, 864-872.

Moreno-Bedmar, J.A., Company, M., Bover-Arnal, T., Salas, R., Maurrasse, F.J., Delanoy, G., Grauges, A., Martínez, R., 2010. Lower Aptian ammonite biostratigraphy in the Maestrat Basin (eastern Iberian Chain, eastern Spain). A Tethyan transgressive record enhanced by synrift subsidence. Geologica Acta 8, 281-299.

Moreno-Bedmar, J.A., Company, M., Sandoval, J., Tavera, J.M., Bover-Arnal, T., Salas, R., Delanoy, G., Maurrasse, F.J.-M.R., Martínez, R., 2012. Lower Aptian ammonite and carbon isotope stratigraphy in the eastern Prebetic Domain (Betic Cordillera, southeastern Spain). Geologica Acta. doi:10.1344/ 105.000001752 .

Morycowa, E., Lefeld, J., 1966. Koralowce z wapieni urgonskich serii wierchowej Tatr polskich. Rocznik Polskiego Towarzystwa Geologicznego 36, 519-542.

Morycowa, E., Marcopoulou-Diacantoni, A., 2002. Albian corals from the Subpelagonian Zone of central Greece (Agrostylia, Parnassos region). Annales Societatis Geologorum Poloniae 72, 1-65.

Moyer, R.P., Riegl, B., Banks, K., Dodge, R.E., 2003. Spatial patterns and ecology of benthic communities on a high-latitude South Florida (Broward County, USA) reef system. Coral Reefs 22, 447-464.

Muscatine, L., Goiran, C., Land, L., Jaubert, J., Cuif, J.-P., Allemand, D., 2005. Stable isotopes $\left(\delta^{13} \mathrm{C}\right.$ and $\left.\delta^{15} \mathrm{~N}\right)$ of organic matrix from coral skeleton. Proceedings of the National Academy of Sciences of the United States of America 102, $1525-1530$.

Olivier, N., Carpentier, C., Martin-Garin, B., Lathuilière, B., Gaillard, C., Ferry, S., Hantzpergue, P., Geister, J., 2004. Coral-microbialite reefs in pure carbonate versus mixed carbonate-siliciclastic depositional environments: the example of the Pagny-sur-Meuse section (Upper Jurassic, northeastern France). Facies 50 , 229-255.

Olivier, N., Lathuilière, B., Thiry-Bastien, P., 2006. Growth models of Bajocian coralmicrobialite reefs of Chargey-lès-Port (eastern France): palaeoenvironmental interpretations. Facies 52, 113-127.

Olivier, N., Pittet, B., Gaillard, C., Hantzpergue, P., 2007. High-frequency palaeoenvironmental fluctuations recorded in Jurassic coral- and spongemicrobialite bioconstructions. Compte Rendu Paleovol 6, 21-36.

Pearson, K., 1926. On the coefficient of racial likeness. Biometrika 18, 105-117.

Perry, C.T., Larcombe, P., 2003. Marginal and non-reef-building coral environments. Coral Reefs 22, 427-432.

Pomar, L., Hallock, P., 2008. Carbonate factories: a conundrum in sedimentary geology. Earth-Science Reviews 87, 134-169.

Reboulet, S., Rawson, P.F., Moreno-Bedmar, J.A., Aguirre-Urreta, M.B., Barragán, R., Bogomolov, Y., Company, M., González-Arreola, C., Stoyanova, V.I., Lukeneder, A., Matrion, B., Mitta, V., Randrianaly, H., Vasicek, Z., Baraboshkin, E.J., Bert, D., Bersac, S., Bogdanova, T.N., Bulot, L.G., Latil, J.-L., Mikhailova, I.A., Ropolo, P., Szives, O., 2011. Report on the 4th International Meeting of the IUGS Lower Cretaceous Ammonite Working Group, the "Kilian Group" (Dijon, France, 30th August 2010). Cretaceous Research 32, 786-793.

Reolid, M., Molina, J.M., Löser, H., Navarro, V., Ruiz-Ortiz, P.A., 2009. Coral biostromes of the Middle Jurassic from the Subbetic (Betic Cordillera, southern Spain): facies, coral taxonomy, taphonomy, and palaeoecology. Facies 55, 575-593.

Riding, R., 2002. Structure and composition of organic reefs and carbonate mud mounds: concepts and categories. Earth-Science Reviews 58, 163-231.

Riegl, B., 2003. Climate change and coral reefs: different effects in two high-latitude areas (Arabian Gulf, South Africa). Coral Reefs 22, 433-446.

Riegl, B., Piller, W.E., 1999. Coral frameworks revisited - reefs and coral carpets in the northern Red Sea. Coral Reefs 18, 241-253.

Rogers, C.S., 1990. Responses of coral reefs and reef organisms to sedimentation. Marine Ecology Progress Series 62, 185-202.

Rosen, B.R., 2000. Algal symbiosis, and the collapse and recovery of reef communities: Lazarus corals across the $\mathrm{K}-\mathrm{T}$ boundary. In: Culver, S.J., Rawson, P.F. (Eds.), Biotic Response to Global Change: the Last 145 Million Years. Cambridge University Press, Cambridge, pp. 164-180.

Rosen, B.R., Aillud, G.S., Bosellini, F.R., Clack, N.J., Insalaco, E., Valldeperas, F.X., Wilson, M.E.J., 2002. Platy coral assemblages: 200 million years of functional stability in response to the limiting effects of light and turbidity. In: Moosa, M.K., Soemodihardjo, S., Soegiarto, A., Rominmohtarto, K., Nontji, A., Soekarno, S., Suharsono, L. (Eds.), Proceedings of the Ninth International Coral Reef Symposium, Bali, Indonesia. Ministry of Environment, Indonesian Institute of Sciences and International Society for Reef Studies 1, pp. 255-264.

Rowan, R., 2004. Thermal adaptation in reef coral symbionts. Nature 430, 742.

Rusciadelli, G., Ricci, C., Lathuilière, B., 2011. The Ellipsactinia Limestones of the Marsica area (Central Apennines): a reference zonation model for Upper Jurassic Intra-Tethys reef complexes. Sedimentary Geology 233, 69-87.

Rützler, K., 2002. Impact of crustose clionid sponges on Caribbean reef corals. Acta Geologica Hispanica 37, 61-72.

Salas, R., Casas, A., 1993. Mesozoic extensional tectonics, stratigraphy, and crustal evolution during the Alpine cycle of the eastern Iberian basin. Tectonophysics 228, 33-55.

Salas, R., Guimerà, J., 1996. Rasgos estructurales principales de la cuenca cretácica inferior del Maestrazgo (Cordillera Ibérica oriental). Geogaceta 20, 1704-1706.

Salas, R., Guimerà, J., Mas, R., Martín-Closas, C., Meléndez, A., Alonso, A., 2001. Evolution of the Mesozoic Central Iberian Rift System and its Cainozoic inversion (Iberian Chain). In: Ziegler, P.A, Cavazza, W., Roberston, A.H.F., CrasquinSoleau, S. (Eds.). Peri-Tethys Memoir 6: Peri-Tethyan Rift/Wrench Basins and Passive Margins. Mémoires du Muséum National d'Histoire Naturelle, Paris 186, pp. 145-186.

Salas, R., Martín-Closas, C., Delclòs, X., Guimerà, J., Caja, M.A., Mas, R., 2005. Factores principales de control de la sedimentación y los cambios bióticos durante el tránsito Jurásico-Cretácico en la Cadena Ibérica. Geogaceta 38, 15-18.

Sanders, D., Baron-Szabo, R.C., 2005. Scleractinian assemblages under sediment input: their characteristics and relation to the nutrient input concept. Palaeogeography, Palaeoclimatology, Palaeoecology 216, 139-181. 
Sanders, D., Pons, J.M., 2001. Stratigraphic architecture of a Santonian mixed siliciclastic-carbonate succession (Catalonian Pyrenees, Spain). Facies 44 105-136.

Scholz, H., 1984. Bioherme und Biostrome im Allgäuer Schrattenkalk (Helvetikum, Unterkreide). Jahrbuch der Geologischen Bundesanstalt 127, 471-499.

Schroeder, R., Van Buchem, F.S.P., Cherchi, A., Baghbani, D., Vincent, B., Immenhauser, A., Granier, B., 2010. Revised orbitolinid biostratigraphic zonation for the Barremian-Aptian of the eastern Arabian Plate and implications for regional stratigraphic correlations. In: Van Buchem, F.S.P., Al-Husseini, M.I., Maurer, F., Droste, H.J. (Eds.), Barremian-Aptian Stratigraphy and Hydrocarbon Habitat of the Eastern Arabian Plate. GeoArabia, Special Publication 4, Gulf Petro Link, Bahrain 1, pp. 49-96.

Scoffin, T.P., Bradshaw, C., 2000. The taphonomic significance of endoliths in dead versus live - coral skeletons. Palaios 15, 248-254.

Skelton, P.W., 2003. The Cretaceous World. Cambridge University Press, Cambridge, 360 pp.

Skelton, P.W., Gili, E., 2012. Rudists and carbonate platforms in the Aptian: a case study on biotic interactions with ocean chemistry and climate. Sedimentology 59, 81-117.

Skelton, P.W., Gili, E., Bover-Arnal, T., Salas, R., Moreno-Bedmar, J.A., 2010. A new species of Polyconites from the uppermost Lower Aptian of Iberia and the early evolution of polyconitid rudists. Turkish Journal of Earth Sciences 19, 557-572.

Stanley, G.D., Jr., 2003. The evolution of modern corals and their early history. EarthScience Reviews 60, 195-225.

Stanley, G.D., Jr., 2006. Photosymbiosis and the evolution of modern coral reefs Science 312, 857-858.
Stanley, G.D., Jr., Helmle, K.P., 2010. Middle Triassic coral growth bands and their implication for photosymbiosis. Palaios 25, 754-763.

Stanley, G.D., Jr., Swart, P.K., 1995. Evolution of the coral-zooxanthellate symbiosis during the Triassic: a geochemical approach. Paleobiology 21,179-199.

Thacker, R.W., Ginsburg, D.W., Paul, V.J., 2001. Effects of herbivore exclusion and nutrient enrichment on coral reefs macroalgae and cyanobacteria. Coral Reefs 19, 318-329.

Thomson, D.P., Frisch, A.J., 2010. Extraordinarily high coral cover on a nearshore, high-latitude reef in south-west Australia. Coral Reefs 29, 923-927.

Tomás, S., Löser, H., Salas, R., 2008. Low-light and nutrient-rich coral assemblages in an Upper Aptian carbonate platform of the southern Maestrat Basin (Iberian Chain, eastern Spain). Cretaceous Research 29, 509-534.

Turnšek, D., Buser, S., Ogorolec, B., 1981. An upper Jurassic reef complex from Slovenia, Yugoslavia. In: Toomey, D.F. (Ed.), European Fossil Reef Models. SEPM, Special Publication, vol. 30, pp. 361-369.

Vennin, E., Aurell, M., 2001. Stratigraphie séquentielle de l'Aptien du sous-bassin de Galvé (Province de Teruel, NE de l'Espagne). Bulletin de la Société Géologique de France 172, 397-410.

Weisser, D., 1959. Acerca de la estratigrafía del Urgo-Aptense en las cadenas Celtibéricas de España. Notas y comunicaciones del Instituto Geológico y Minero de España 55, 17-32.

Wood, R.A., 1998. The ecological evolution of reefs. Annual Review of Ecology and Systematics 29, 179-206.

Wood, R.A., 1999. Reef Evolution. Oxford University Press, Oxford, 414 pp.

Zamagni, J., Mutti, M., Košir, A., 2012. The evolution of mid Paleocene-early Eocene coral communities: how to survive during rapid global warming. Palaeogeography, Palaeoclimatology, Palaeoecology. doi:10.1016/j.palaeo.2011.12.010. 